\title{
Lost in Translation? The Idea of the Garden City and its Migration to the Czech Lands, 1900-1938
}

\author{
Vendula Hnídková (hnidkova@udu.cas.cz) \\ Institute of Art History, Czech Academy of Sciences, Prague, Czech Republic
}

\begin{abstract}
The article is the first introduction to the garden city movement in the Czech lands. The dynamic transformations of its trajectory are highlighted by selected upheavals. It spans from its cautious beginnings in the first decade of the twentieth century to its climax in the 1920s, and a singular appropriation of the urban vision by the Czechoslovak government in the 1930s. Encompassing the turbulent era, the way in which the garden city utopia was approached exposes not only implementation of the modern urban concept but also the constant response to political transformations underlined by Czech and Germans conflicts in what was to become interwar Czechoslovakia.
\end{abstract}

\section{Keywords}

Garden City; Modern Town Planning; Central Europe; Ebenezer Howard; Raymond Unwin; Jan Kotěra; Zlín; Bata; Hermann Muthesius; Prague; Masaryk.

https://doi.org/10.5817/AEC2021-1-4 


\section{Lost in Translation? The Idea of the Garden City and its Migration to the Czech Lands, 1900-1938}

\section{Vendula Hnídková}

The history of the garden city movement in the Czech lands is a story that remains to be explored, scrutinized, and reconstructed for the first time. ${ }^{1}$ In comparison with other countries, not in Europe, where the adoption and afterlife of Ebenezer Howard's reform vision has been thoroughly documented, the history of modern architecture and town planning in the Czech territories of Bohemia, Moravia and Moravian Silesia, lacks any comparable study. ${ }^{2}$ Yet, even from initial research it is apparent that the adoption of the English scheme in the Czech lands was significant because it was always inextricably linked to political transformations.

The garden city movement has its Czech roots in the beginning of the twentieth century. Long before the astonishing growth of Prague and Brno in the interwar era, there were dedicated advocates of the English reform scheme, and when Prague first emerged as the Czechoslovak capital, many Czech patriots enthusiastically generated visions devoted to new urban design and city planning. The instrumental point of departure that unfolds the history of the garden city movement in the Czech lands seems to be closely linked to fundamental political change in the region.

We can get a sense of its political importance from the fact that some of the advocates of the garden city movement indicated an exact point of departure for the adoption of approaches to town planning based on Ebenezer Howard's reform principles in the Czech lands. The architect Alois Kubíček (1887-1970), one of its chief supporters, pointed out that the very beginning of the movement was precisely 28 October 1918, ${ }^{3}$ the date of the foundation of Czechoslovakia. He linked it in a straightforward way to the realisation of an actual utopia, namely the founding of the new Republic, with an accompanying urban utopia that took the form of the garden city, albeit one that, ultimately, was never realised there in its complexity. For many of its local advocates, the merger the new political system, epitomised by the newly formed democratic country, with a new social order linked based on the garden cities movement, proved to be an enormously promising vision.

1) This article is part of a project: Idea, Ideal, Idyll: Garden Cities in Central Europe 1890s-1930s, which has received funding from the European Union's Horizon 2020 research and innovation programme under the Marie SkłodowskaCurie grant agreement No 798686.

2) Liora Bigon and Yossi Katz, eds., Garden Cities and Colonial planning. Transnationality and Urban Ideas in Africa and Palestine, Manchester: Manchester University Press, 2014.

3) A. K. [Alois Kubíček] and Vladimír Zákrejs, 'Praha budoucí, projekty zítřka,' Styl, 3, 1922-1923, 141. 


\section{Masaryk City}

In Czechoslovakia the move towards combining the new democratic government with unparalleled urban visions was blended in a very singular town planning objective in the aftermath of the First World War. In 1920, for example, an anonymous author hidden behind the letter ' $\mathrm{R}$ ' outlined an elusive vision of both urban development in Prague and the eventual political satisfaction of the Czech national aspirations in Časopis československých inženýrüv a architektův, one of the main journals of engineering and architecture in the new state. Proposing the construction of a new settlement on the outskirts of the city on the site of the historic battle of the White Mountain, he noted:

In a historical place where the tragedy of 1620 took place, the tragedy in which the Czech nation lost its independence, a garden city should become a living and dignified monument of our national liberation. [...] Its construction is to be started in 1920, just 300 years after the Battle of White Mountain, and should bear for everlasting memory the name of the leader of our liberation by being named Masaryk City. ${ }^{4}$

The use of the name of the first Czechoslovak president, Tomáš Garrigue Masaryk (18501937), for the planned settlement at White Mountain, would contribute to emphasising the legitimacy of a historical claim that the lands of the Bohemian crown belonged eventually and exclusively to Czechs, or the newly invented construction of the Czechoslovak nation in particular. Moreover, the garden city bearing the president's name would be a significant contribution to the cult of personality of the first Czechoslovak leader (Figure 1).

Masaryk's authority and his cult of personality was a key phenomenon in Czechoslovak identity during the interwar period and long after. T. G. Masaryk, a philosopher and sociologist by education and profession, had already become involved in politics in the late nineteenth century. However, at the end of the war, his sophisticated, visionary, and often dangerous mission in exile, namely, that of securing political independence for Czechs and Slovaks, eventually succeeded in the founding of the Czechoslovak Republic on 28 October 1918. His triumphant return later that year to Prague from the United States, where he had been promoting the cause of Czechoslovak independence, confirmed his prominent position, which lasted until his death in 1937. Masaryk, being a philosopher, advocated a very specific view of humanity based on the heritage of Protestantism which he summarized in his book The Czech Question. ${ }^{5}$ The medieval Reformation, represented by Jan Hus (1372-1415), Petr Chelčický (1390-1460), and the Hussite movement manifested, according to Masaryk, 'the virtues of modernity: the cultivation of reason, altruistic service for one's neighbours, and a democratic, non-hierarchical form of social organization. ${ }^{6}$ To cherish his singular legacy,

4) R., 'Zahradní město na Bílé Hoře', Časopis československých inženýrưv a architektův, 19:1, 1920, 10: 'Na historickém místě, kde odehrála se tragédie r. 1620, kterou národ český ztratil svoji samostatnost, má stát zahradní město jako živý a důstojný pomník našeho národního osvobození. [...] Se stavbou jeho se má počít roku 1920, tedy právě 300 rokủ po bitvě bělohorské, a má nésti pro věčnou pamět jméno vůdce našeho osvobození a slouti Masarykovo město.'

5) Tomáš Garrigue Masaryk, Česká otázka. Snahy a tužby národního obrozeni [The Czech question: the pursuit and desire for national revival], Prague: Čas, 1895.

6) Bruce R. Berglund, Castle and Cathedral. Longing for the Sacred in a Sceptical Age, Budapest and New York: Central European University Press, 2017, 43. 


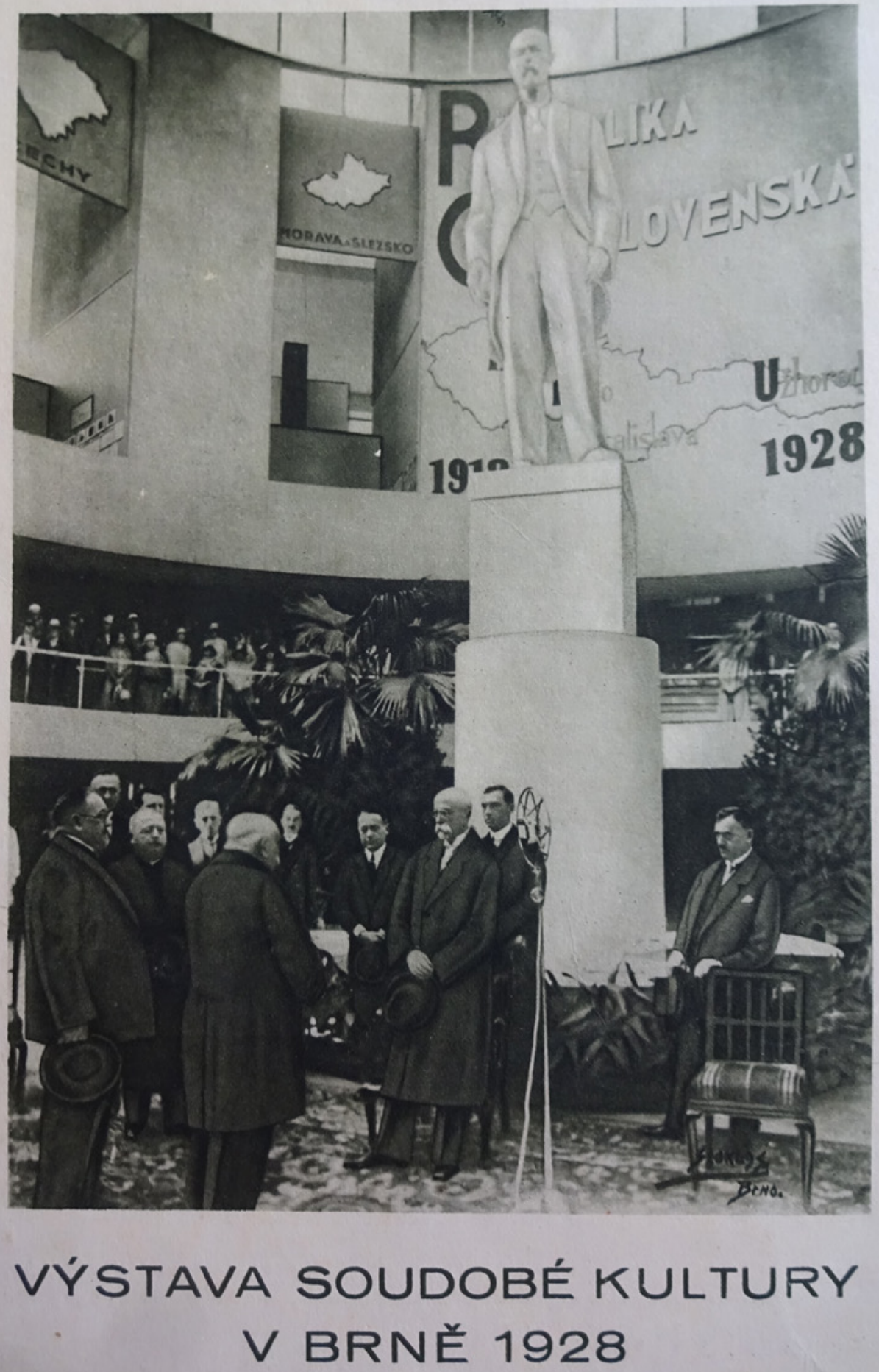

Figure 1: The Czechoslovak president Tomáš Garrigue Masaryk in front of a statue depicting him at the Exhibition of Contemporary Culture in Brno, 1928.

From: Almanach Výstavy soudobé kultury, Brno, 1928. 
Masaryk's compatriots used his name on a massive scale to name in his honour squares, schools, and many other public institutions. Masaryk City would be hardly an exception, but an early example of the personality cult first president.

The planned Masaryk City became the focus of intense utopian ideals that found a particularly strong resonance among the Czechs. Though there are no plans or descriptions of the urban design in existence, and the town planners of the zealous vision remain so far anonymous, their message is obvious. Since the nineteenth century, White Mountain has been treated as a symbolic location of crucial importance by the members of Czech national movement. Hence, the unprecedented aim of erecting a vast garden city based on an English model at White Mountain in Prague, to be populated by Czech 'legionaries,' in other words, the veterans of the First World War and the Russian Civil War, precisely in 1920 suggests that Ebenezer Howard's scheme was assumed to be the appropriate medicine to heal not only the neglected housing situation in the Czechoslovak capital but, first and foremost, the Czech national trauma. ${ }^{7}$

In fact, the trauma, deeply rooted in the decisive defeat at the Battle of White Mountain, meant not only the beginning of the Thirty Years' War in Europe but, moreover, had grave consequences for the lands of the Bohemian crown. The defeat of the Bohemian forces in the battle led to confirmation of Habsburg rule and forced re-catholicization and the introduction of an entirely new, mainly foreign, ruling elite. In the nineteenth century, Czech historiography merged the painful memory of past and present foreign rule together with a nostalgic longing for the mythical distant past. The popular author Alois Jirásek coined an apt name for this period that ended in 1918, when he published a historical novel in 1915 about the period of recatholicization, giving it the title The Dark Time (Temno). ${ }^{8}$ Deeply rooted in the legacy of historians such as František Palacký and Ernest Denis, the dominant narrative that accompanied the establishment of Czechoslovakia saw it as expression of historical satisfaction after almost three hundred years of the alienation of Czechs at the hands of the Habsburg Monarchy. ${ }^{9}$ This foreign rule was to be erased by various symbolical manifestations in the public realm, and the envisioned garden city at White Mountain was one of them.

The ambitions to reform town planning on the one hand would also commemorate a keystone of the Czech national identity on the other. And the anticipated residents, the legionaries, would overcome the historical loss with an ultimate victory. This aggregate of historical and modern meanings was characteristic of the ways that national identity in interwar Czechoslovakia was framed.

7) František Fabinger, 'Zahradní město a bytová otázka,' [The garden city and the question of housing], Družina československých legionár̆ů, 1: 1, January 1920, [3].

8) Alois Jirásek, Temno, Prague: Jan Otto, 1915.

9) Josef Petráň, 'Na téma mýtu Bílé hory,' [On the theme of the myth of White Mountain] in Zdeňka Hledíková, ed., Traditio et cultus: miscellanea historica Bohemica, Prague: Karolinum, 1993, 141-162. 


\section{An English scheme for the Czech lands}

Yet, 'the living and dignified monument of our national liberation' in the form of a garden city to be established at White Mountain also suggests that some saw a straight political affinity between the newly founded Czechoslovakia and the international garden city movement with its British origins. In other words, the garden city movement would highlight the links between the new democracy and a traditional one abroad. In this sense, the avid interest in adopting the English model in Czechoslovakia in the early 1920s suggests that it may be understood as to some degree linked to Czechoslovak official policy towards the United Kingdom.

In fact, Czech municipal representatives in Prague, who won ground-breaking elections in 1861 for the first time and replaced their German predecessors ever since, had striven for some time for political autonomy from their Habsburg rulers. The local authorities had already demonstrated their independence from the imperial administration in Vienna by creating conscious links with other European powers - especially France and Great Britain - in the late nineteenth century. From a political point of view, the strategy of the city of Prague achieved a notable, if limited, success that reached its climax at the turn of the century. ${ }^{10}$ In 1897 the French Republic opened a consulate in Prague; this was only its second consulate after that in the United States, followed by offices in Switzerland and Great Britain later that year. Such a positioning of Prague, a capital without a country, on the political map of Europe, in which not even Vienna had a French embassy or consular presence from among other leading world powers of the day, proved to be truly exceptional. ${ }^{11}$

Effective networking by Czech political representatives in Prague made these endeavours visible on an international level within a few decades. In 1900, a delegation of Czech representatives of the Prague municipality led by the mayor Vladimír Srb was reciprocally welcomed with official honours by French politicians in the town hall in Paris. In addition, the highest representatives of the municipality of Paris paid a subsequent visit to Prague at the turn of June and July $1901 .^{12}$ But the French Republic was not the only place of interest. Anglo-Czech relations also blossomed, and the United Kingdom was highly admired as the model of a modern industrialized nation. Paralleling the enormous cultural interest in Great Britain was a vivid political exchange between Prague and London that culminated in the 1911 visit of Lord Mayor of London, Sir Thomas Vezey Strong, to the Czech capital. The Lord Mayor's official visit precisely coincided with the founding of the first garden city to be built in Prague. ${ }^{13}$

10) Jiří Kořalka, 'Zahraniční kontakty Prahy jako metropole národa bez státu' [The foreign contacts of Prague as the metropolis of a nation without a state] in: Václav Ledvinka and Hana Svatošová, eds, Město a jeho dům: Kapitoly ze stoleté historie Obecního domu hlavního města Prahy (1901-2001) [The city and its house: chapters from the hundred-year history of the Municipal House of Prague the capital city], Prague: Obecní dům / Prague City Archive, 2002, 29-39.

11) 'Francouzský konsulát v Praze,' [The French consulate in Prague], Národní listy, 37: 201, 22. 7. 1897, 2-3.

12) 'Na radnici staroměstské' [On the town hall of the Old Town], Národní listy 41: 179, 1. 7. 1901, 1-2; 'Vása sèvresská darem Pařiže obci pražské' [A Sèvres vase as a gift from Paris to the municipality of Prague], Národni listy 41: 180, 2. 7. 1901, 2; 'K pobytu francouzských hostí v Praze' [On the stay of French guests in Prague], Národní listy 41: 184, 6. 7. $1901,3$.

13) Stefan Muthesius, Das englische Vorbild: Eine Studie zu den deutschen Reformbewegungen in Architektur, Wohnbau und Kunstgewerbe im späteren 19. Jahrhundert, Munich: Prestel, 1974. 
Although the cultural and political parallels seem logical and promising, understanding the lively interest in English garden cities in Czechoslovakia in the aftermath of the First World War solely from the perspective of political cooperation with Western Europe would lead to a significant simplification. In fact, to disprove the initial assumption, it is not necessary to leave Central Europe at all. Germany and Austria-Hungary, two leading states of the Central Powers in the war, both belonged among the chief sympathisers of the garden city movement in the region. In Europe in general, a vivid fascination with the United Kingdom had flourished since the eighteenth century. ${ }^{14}$ Several waves of interest in British culture could be observed in Central Europe in particular, starting with admiration for landscape gardens around 1800, then Neo-Gothic revival of medieval forms in the first half of the nineteenth century and, eventually, the domestic housing by the end of the century. ${ }^{15}$ In this brief cultural genealogy one should emphasize that the Deutsche Gartenstadt-Gesellschaft, founded already in 1902 in Berlin, was the first foreign offspring of the Garden City Association established by Ebenezer Howard only three years earlier. ${ }^{16}$

In this sense, the desire to build the garden city of Masaryk City at White Mountain, refers more to a rebirth of Czech sovereignty than to a new stage of the garden city movement in Central Europe. Furthermore, the Czechoslovak fascination with the garden city scheme in the 1920s cannot be interpreted as the mere reflection of a political alliance with Great Britain, but rather as a more complex aspiration to reform the urban and social milieu according to the respected English model.

\section{A peaceful path to real reform}

The garden city scheme was defined by Ebenezer Howard (1850-1928), a stenographer by profession but also a social reformer, in his extraordinarily influential book To-morrow: A Peaceful Path to Real Reform published in 1898, which became better known under its revised title Garden Cities of Tomorrow, published only four years later. ${ }^{17}$ The original name of the book highlights the fact that Howard emphasized a peaceful and gradual transition to new urban and social forms instead of any rapid revolution. In times of dramatic social unrest, he mobilized far less violent forces to achieve his ultimate goal of transforming society by way of calm evolution, which meant building new garden cities instead of fuelling violent revolution on the streets of the existing ones. In the principles of self-contained and self-governed communities he outlined, Howard assumed that any efficient municipal reform must be linked with a new social order. In terms of the existing social class divisions of the turn of the century in the United Kingdom, his project was progressive, given its aim of including both workers together

14) Ian Buruma, Anglomania: a European Love Affair, New York: Random House, 1999.

15) Jakob von Falke, 'Das englische Haus,' in Falke, Zur Kultur und Kunst, Vienna: Gerold, 1878, 3-67; Robert Dohme, Das englische Haus: Eine kultur- und baugeschichtliche Skizze, Brunswick: Westermann, 1888; Hermann Muthesius, Die englische Baukunst der Gegenwart: Beispiele neuer englischer Profanbauten, Leipzig: Cosmos, 1900.

16) Tobias Roth, ed., Gartenstadtbewegung: Flugschriften, Essays, Vorträge und Zeichnungen aus dem Umkreis der Deutschen Gartenstadt-Gesellschaft, Berlin: Verlag Das Kulturelle Gedächtnis, 2019, 234.

17) Ebenezer Howard, To-morrow. A Peaceful Path to Real Reform, London: Swan Sonnenschein, 1898; Ebenezer Howard, Garden Cities of Tomorrow, London: Swan Sonnenschein, 1902. 
with members of the middle-class professions in the new settlement. ${ }^{18}$ Howard's urban vision of a garden city was an attempt to articulate the issues that need to be addressed to make a city a good and inclusive place to live for everyone, privileged or unprivileged.

Amongst the essential differences between Garden City and other municipalities, one of the chief [sic] is its method of raising its revenue. Its entire revenue is derived from rents; [...] the rents which may very reasonably be expected from the various tenants on the estate will be amply sufficient, if paid into the coffers of Garden City, (a) to pay the interest on the money with which the estate is purchased, (b) to provide a sinking fund for the purpose of paying off the principal, (c) to construct and maintain all such works as are usually constructed and maintained by municipal and other local authorities out of rates compulsorily levied, and (d) (after redemption of debentures) to provide a large surplus for other purposes, such as old-age pensions or insurance against accident and sickness. ${ }^{19}$

Soon after, the scheme proved to be truly vital when he was provided with the opportunity to implement it in the real world. In 1903, only one year after Garden Cities of Tomorrow was published, the first garden city, Letchworth, was established in Hertfordshire, thirty five miles northeast of London, employing the dynamic infrastructure of modernity, since it was located on a direct train line to London. ${ }^{20}$ Architects and town planners at the beginning of their careers, Raymond Unwin and Barry Parker, won the competition to translate Howard's vision into the new settlement. Within a couple of years, Letchworth became a focal point for new town planning and housing reform that attracted many reformers from overseas who left overwhelmed by the new community.

\section{Introducing the English vision in Central Europe}

There were a number of keen advocates of garden cities in Central Europe, first of all in Germany, the leading industrial power along with the United Kingdom and in this sense experiencing problems with overcrowded towns, filthy tenements, and poor living standards. From the beginning of the twentieth century, the Deutsche Gartenstadt-Gesellschaft promoted Howard's concept enthusiastically. ${ }^{21}$ Their campaigning was fulfilled in 1909 when the industrialist Karl Schmidt established the first German garden city, Hellerau, near Dresden. ${ }^{22}$

Hellerau attracted a number of visitors from Prague and Bohemia, but the Czech advocates of the garden city movement were not as flexible nor as well prepared to adopt the innovative vision as their German predecessors at that time due to their having more limited access

18) Robert H. Kargon and Arthur P. Molella, Invented Edens: Techno-Cities of the Twentieth Century, Cambridge, MA: MIT Press, 2008, 7-24.

19) Howard, Garden Cities of Tomorrow, 28.

20) Mervyn Miller, Letchworth: The First Garden City, Felpham: Phillimore, 1989; Josh Tidy, Letchworth Garden City Through Time, Stroud: Amberley, 2015.

21) Die deutsche Gartenstadtbewegung: zusammenfassende Darstellung über den heutigen Stand der Bewegung, Berlin: Verlag der Deutschen Gartenstadt-Gesellschaft, 1911.

22) Nils M. Schinker, Die Gartenstadt Hellerau 1909-1945: Stadtbaukunst, Kleinwohnungsbau, Sozial- Und Bodenreform, Dresden: Sandstein Verlag, 2014. 
to financial resources, a general emphasis on national instead of social issues, and lack of any leading association that would focus solely on promoting the English scheme. ${ }^{23}$ Yet, the example of Hellerau proved to be enormously powerful at this early stage, and it demonstrates that even though there were considerable nationalist political tensions between Germans and Czechs, there could still be a high degree of cultural exchange. ${ }^{24}$

In the Czech lands of Bohemia and Moravia, long before the breaking point of 1918 that Alois Kubíček marked as the very beginning of the garden city movement in the region, a diverse community, advocating Howard's urban utopia, emerged. The small body of these early proponents of garden cities from the first two decades of the twentieth century may be divided into two main groups. Not surprisingly, on the one hand they were recruited chiefly from the long tradition of national revivalists based in several small towns that were predominantly Czech. To name a few: the general practitioner Zdenko Eger from Dvůr Králové nad Labem; Dr. Emil Halla, a solicitor from Bučovice; Karel Kašpara, a building contractor from Pardubice; the architect Jaroslav Kohoutek, from Chrudim; the Tábor-based building contractor and a head of a building co-operative, Karel Rudolf, and the engineer Eduard Wosatka from Lovosice. ${ }^{25}$ These were members of the local educated class: builders, doctors, and lawyers. On the other hand, a number of garden city advocates came from a very different part of the social spectrum, namely from the cultural circles that followed the latest trends in modern architecture and formed an architectural section in the Association of Fine Artists Mánes (Spolek výtvarných umělců Mánes) based in Prague. ${ }^{26}$

The first Czech garden city sympathisers shared and discussed their latest knowledge of the English scheme in the context of various associations, ranging from the Czech National Economic Society (Česká společnost národohospodářská), founded in 1896, and the Union of Czech Cities in the Kingdom of Bohemia (Svaz českých měst v království Českém) founded in 1907, to the Czech Provincial Association for Housing Reform in the Kingdom of Bohemia (Český zemský spolek pro reformu bytovou v království Českém), founded in $1910 .{ }^{27}$

In 1911, several members of the Czech Provincial Association for Housing Reform, including the architect Jaroslav Kohoutek, attended a conference in London convened by the National Housing and Town Planning Council. ${ }^{28}$ On their way to London, they visited a number of model housing estates such as Port Sunlight, Bournville, Hampstead Garden Suburb, Letchworth, and before reaching Britain they also went to Hellerau. The overwhelming impact of the study trip is well recorded in many articles and, moreover, Karel Rudolf, an architect, building contractor, and the head of a building cooperative in the small town of Tábor, published a book

23) Rudolf Wels, Zahradová města [Garden cities], Prague: Pokrok, 1911, 13-14.

24) Ladislav Blažej, 'Zahradní město Hellerava' [The garden city of Hellerau], Architektonický obzor, 10: 9, 1911, 82-84.

25) Jaroslav Kohoutek, 'Mezinárodní sjezd spolků pro bytovou reformu úřednických a dělnických obydlí v Londýně' [The international congress of societies for housing reform for the dwellings of civil servants and workers], Národní listy, 51: 214, August 1911, 5.

26) The media platform of Mánes was the architectural journal Styl.

27) 'K prvnímu sjezdu českých bytových a stavebních družstev' [On the first congress of Czech societies for housing and building], Čas, 25: 284, 14. 10. 1911, 8.

28) Kohoutek, 'Mezinárodní sjezd' (as in n. 25), 5. 
dedicated entirely to his observations from the grand tour. ${ }^{29}$ Considering the vast reflections in the media, the trip to England might be underlined as an actual point of departure for the more efficient dissemination of garden city ideas in the Czech lands. ${ }^{30}$ It was also parallelled, in 1911, by a travelling exhibition staged by the Deutsche Gartenstadt-Gesellschaft in Prague, Chrudim, Hradec Králové, and Kolín. ${ }^{31}$

The exhibition was accompanied by a catalogue assembled by Ladislav Blažej. ${ }^{32}$ In the Introduction he underlined the meaning of the scheme for the Czech lands:

A garden city cannot be imagined as any city with gardens - they must not be missing - but their key principle is the economic basis, attached with all aesthetic and cultural requirements that support the healthy mental and physical development of its inhabitants. Thus, a city, in the case of a suburb or settlement, based on open space using an economic method that would permanently prevent any speculation in building plots in the future. ${ }^{33}$

A garden city as a reform device to improve unsatisfactory living standards and in this respect the whole of society; this was the brief message articulated by Blažej and displayed to the public in four towns in 1911. Blažej was the driving force in importing the German exhibition on garden cities to the Czech lands and initiating an association committed to setting up the model settlements. ${ }^{34}$ But his objective was only fulfilled ten years later, in 1921, when the Society for the Establishment of Garden Cities in the Czechoslovak Republic (Společnost pro zakládání zahradních měst v republice Československé) started to operate. ${ }^{35}$

Along with Blažej, other professionals familiar with the garden city movement were architects and town planners whose early activities remain largely overseen by the local art historiography. Alois Kubíček promoted garden cities to the Association of Architecture Students (Spolek posluchačů architektury) in 1909. ${ }^{36}$ The Prague-based art historian Zdeněk Wirth also prepared a series of talks on English housing and garden cities in $1910 .{ }^{37}$

29) Karel Rudolf, Anglická zahradní města: Doncaster, Hull, New Earswick, Bournville, Romford, Hampstead [The English garden cities: Doncaster, Hull, New Earswick, Bournville, Romford, Hampstead], Tábor: self-published, 1912.

30) Jaroslav Kohoutek, 'Mezinárodní sjezd spolku pro bytovou reformu úřednických a dělnických obydlí v Londýně' [The international congress of societies for housing reform for the dwellings of civil servants and workers], Stavitelské listy, 7:20, 1911, 164-165; 7: 21, 1911, 173-175; 7:22, 1911, 181-185; 8:1, 1912, 6-7; 8:3, 1912, 20-21; 8:4, 1912, 27-31; 8:5, 1912, 39-40 and 8:7, 1912, 55.

31) Vladimír Zákrejs, 'Výstava zahradních měst’ [A garden city exhibition], Styl, 3, 1911, 250-251; 'Výstava zahradních měst a rodinných domků' [An exhibition of garden cities and family homes], Čas, 25: 305, 4 November $1911,3$.

32) Ladislav Blažej, ed., Výstava zahradních měst [A garden city exhibition], Prague: Dělnická knihtiskárna, 1911.

33) Ladislav Blažej, 'Předmluva' [Foreword], in ibid. 'Zahradním městem nelze si představovati všelijaké libovolné město se zahradami - těch při nich chyběti nesmí - nýbrž hlavním jejich principem jest hospodářský podklad, spojený se všemi estetickými a kulturními požadavky, které podporují zdravý duševní a tělesný vývoj jeho obyvatelů. Tedy město, po př́ípadě předměstí neb osada, založená na volném prostranství použitím hospodářské method, jež by v budoucnosti trvale zabránila spekulaci se stavebními pozemky.'

34) Vladimír Zákrejs, 'Zahradní město u nás' [The garden city in our lands], Styl, 4, 1912, 68.

35) Z, 'Společnost pro zakládání zahradních měst v republice Československé' [The Society for the establishment of garden cities in the Czechoslovak Republic], Časopis československých inženýrův a architektův, 20: 12, 1921, unpaginated.

36) 'Spolkový věstník' [The society bulletin], Čas, 23: 307, 7 November 1909, 8.

37) 'O kultuře moderního obydlí a uměl. řemesle' [On the culture of modern housing and design], Čas, 24: 317,17 November 1910, 10. 
Among the garden enthusiasts in the architectural section of the Association of Fine Artists Mánes, such as Rudolf Stockar and Vladimír Zákrejs, who published articles in the respected architectural journal Styl, the influence of the most important of them, Jan Koterra, remains somewhat invisible, for he wasn't very productive as an author. But it is highly probable that Kotěra became acquainted with Howard's urban vision during his frequent travels abroad, which included several visits to the United Kingdom at the beginning of the twentieth century when he was in contact with the Royal Institute of British Architects. ${ }^{38}$ Moreover, his personal relationship with Hermann Muthesius, the Prussian architect, author, career civil servant and cultural attaché in London, deserves a mention as well. ${ }^{39}$ Muthesius was a noted anglophile and became an established expert on modern English housing, which he promoted in the three volumes of his book The English House (1904). ${ }^{40}$ Kotěra contributed to dissemination of his knowledge in the Czech architectural circles. ${ }^{41}$

In this initial stage, when the first Czech garden city sympathisers travelled to both Germany and the United Kingdom to explore early model villages and garden cities, the idea of reform was already flourishing in Prague. The initial pioneer, who was determined to translate the English scheme into reality, was not an architect nor a town planner but the wealthy landowner Tomáš Welz. In 1911 he summarized his urban vision in a luxuriously designed pamphlet entitled The Garden City in Bráník and Krč: The Residential Area in Prague XIII. ${ }^{42}$ The reference to 'residential area' in the English translation does not convey the connotations of the original 'villová čtvrt' in the original Czech title, which reveals Welz's understanding of the garden city, as a collection of family houses, villas, in a green environment on the outskirt of Prague. In the outline building programme there was no place for any social reform.

Welz possessed large estates in Krč, a small village south of Prague that became part of Greater Prague in 1922; at the beginning of the twentieth century it was only a large piece of open land dotted by some houses. The beautiful, hilly, and forested landscape and its proximity to the town, which was accessible by train from the local station, made Krč attractive for various business undertakings that sought to profit from the green countryside, which had remained unspoiled by any industrial production long into the modern era. Welz himself resided with his family in a Neo-gothic castle in the lush green environment.

From the very beginning, the developer's intention was denounced by local architects. They argued that Welz only took an advantage of the name to appeal to future residents of the housing estate, avoiding the complex social programme inherent in the English scheme. ${ }^{43}$ But that was only a half-truth, at least in terms of town planning. A detailed scrutiny of the master plan conceived by the little known engineer and builder František Matějovský reveals

38) 'Report of the Literature Standing Committee,' Journal of The Royal Institute of British Architects, 11, $1904,362$.

39) Vladimír Šlapeta, 'Architekt Jan Kotěra' [The architect Jan Kotěra], in Šlapeta, ed., Jan Kotěra 1871-1923: Zakladatel moderni české architektury [Jan Kotěra 1871-1923: The founder of modern Czech architecture], Prague: KANT, $2001,31$.

40) Hermann Muthesius, Das englische Haus: Entwicklung, Bedingungen, Anlage, Aufbau, Einrichtung und Innenraum. Entwicklung des englischen Hauses, Berlin: Ernst Wasmuth, 1904-5, 3 volumes.

41) Vladimír Šlapeta, 'Gartenstädte in Tschechien und in der Slowakei. Geschichte und Gegenwart,' in Thomas Will und Ralph Lindner, eds., Gartenstadt. Geschichte und Zukunftsfähigkeit einer Idee, Dresden: w. e. b. Universitätsverlag, 2012, 180-181.

42) Tomáš Welz, Zahradní město v Bráníku a v Krči: villová čtvrt'v Praze XIII [The garden city in Bráník and Krč: a villa quarter in Prague XIII], Prague: self-published, [1911].

43) Rust [Rudolf Stockar], 'Zahradní město v Krči' [The garden city in Krč], Styl, 3, 1911, 211-212. 


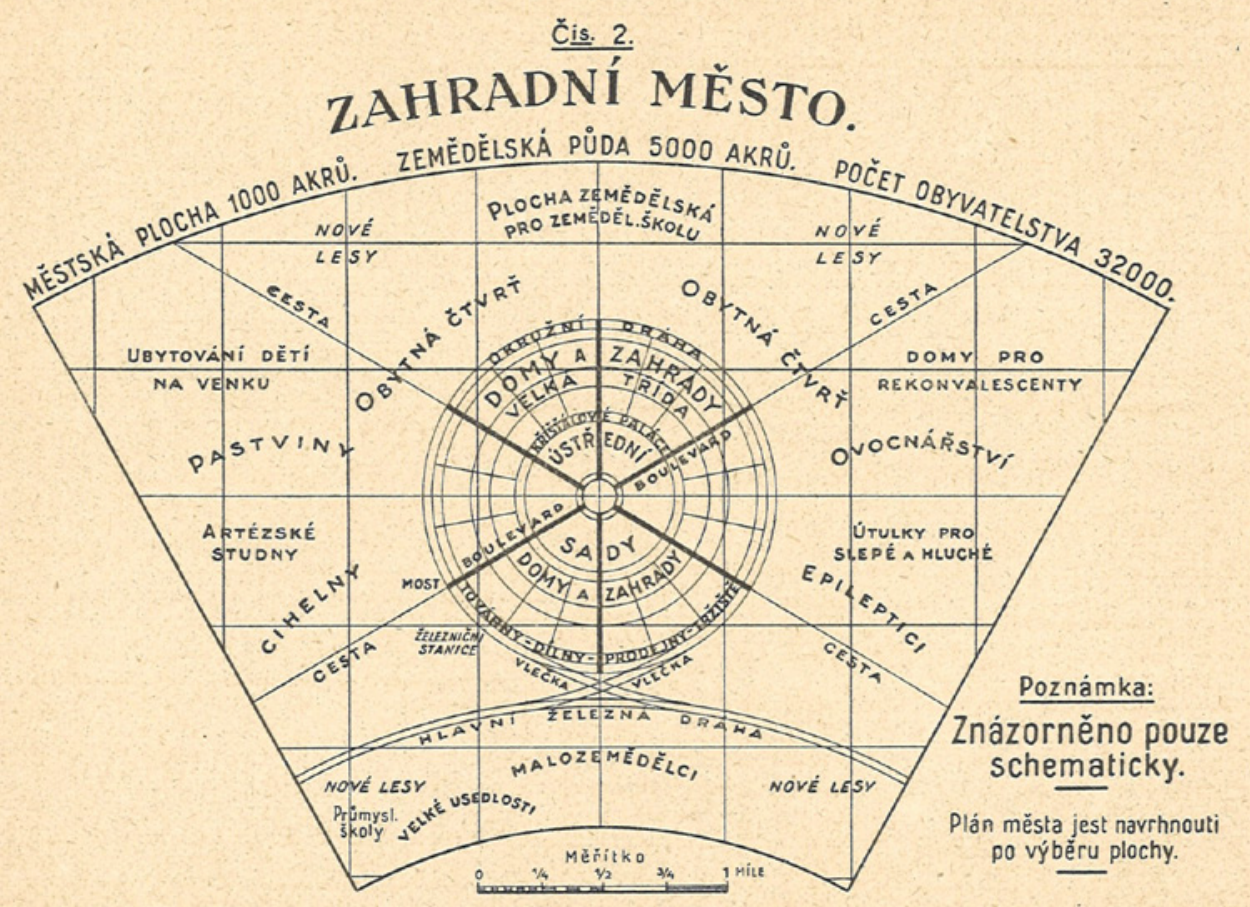

Figure 2: Ebenezer Howard, Garden city scheme, 1902.

From: Ebenezer Howard, Zahradní města budoucnosti, Prague. 1924.

a close reading of Ebenezer Howard's diagram. Howard accompanied his treaties with a series of diagrams that were to be comprehended as mere schematic sketches of his visions which he repeatedly pointed out. ${ }^{44}$ Regardless of how schematic the diagrams were, they proved to be an instrumental urban plan for many of his successors (Figures 2 and 3).

Unlike Raymond Unwin and Barry Parker in Letchworth, Matějovský took Howard's lesson seriously and applied the concentric pattern in a rather orthodox way in Krč regardless of the nature of the chosen plot. Moreover, the rigid adoption of the envisioned ideal is emphasised by the street names such as V Kole (In the Circle), Paprsková (Radial), and U Společenské zahrady (By a Community Garden). From the pamphlet it also becomes obvious that Welz planned a mere garden suburb, avoiding the erection of any public buildings, which thus kept the dwellers fully dependent on the then remote Prague (Figure 4). ${ }^{45}$

The first implementation of the garden city scheme in the Czech lands was limited to a smart advertisement for middle-class clients. Any social reform strategies that were part of Howard's original vision were omitted in Prague as the building programme pursued different objectives. However, the vision set up in 1911 was soon jeopardized by the war. Eventually, only a part of the lay-out was completed and just a few family houses, designed chiefly by

44) Howard, Garden Cities of Tomorrow, unpaginated.

45) Welz, Zahradní město, unpaginated. 


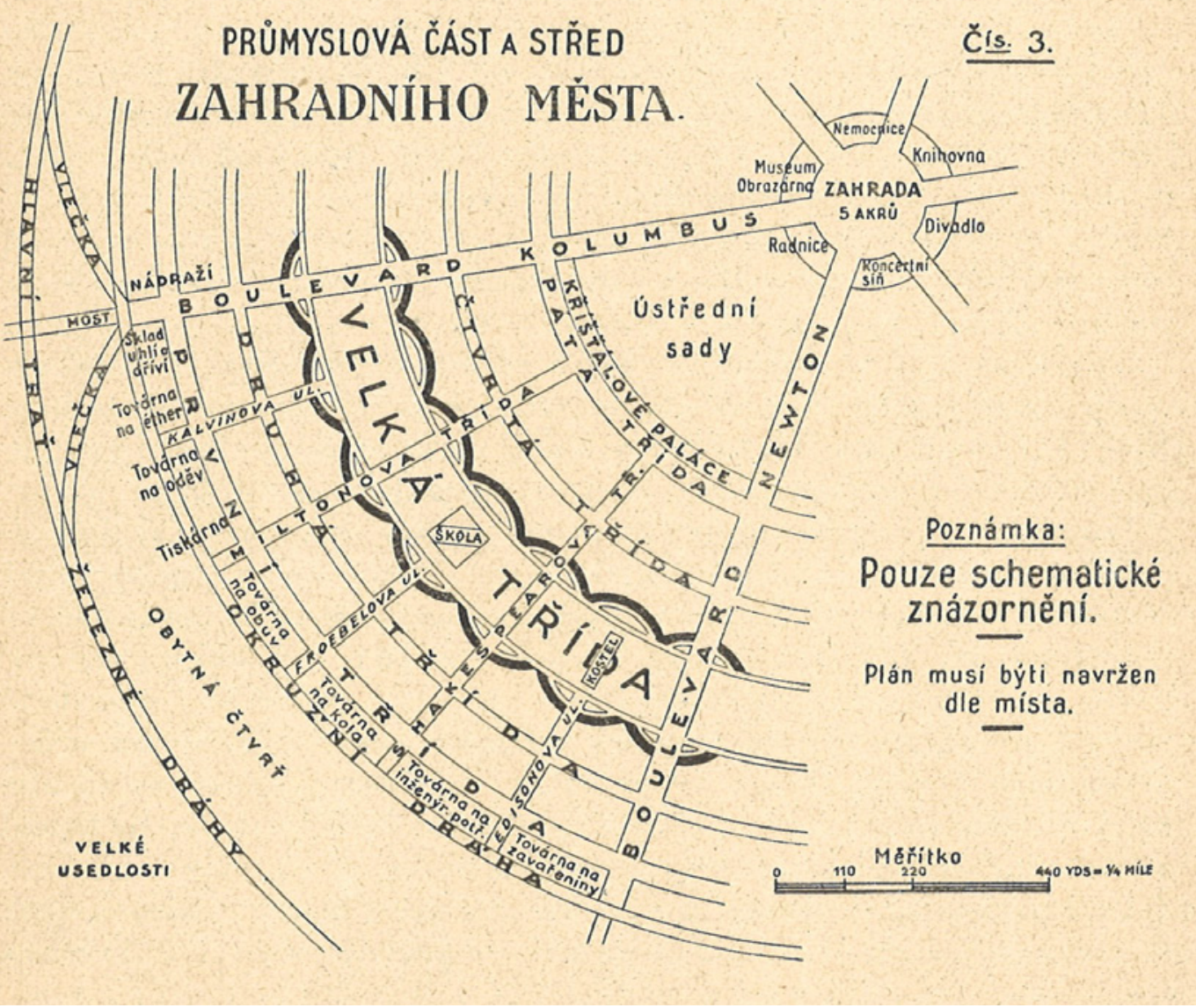

Figure 3: Ebenezer Howard, Detail of garden city, 1902.

From: Ebenezer Howard, Zahradní města budoucnosti, Prague. 1924.

a local builder Rudolf Tuhý from Nusle near Prague, were constructed. Their decorative style reveals some inspiration in geometric forms of Viennese modernism as in the work of Joseph Maria Olbrich (Figures 5 and 6).

In the pre-war period, the transmission of the garden city movement know-how between the United Kingdom and the Czech lands was often mediated by better-informed German professionals. Their early contact with Howard's scheme led to a fruitful variety of transformations, disseminations, and adoptions of the English urban theory in Germany. Yet, the German example proved also limiting in terms of the appropriation of the concept as a garden suburb or workers' colony (Figure 7). ${ }^{46}$

46) Wolfgang Pehnt, Deutsche Architektur seit 1900, Munich und Ludwigsburg: Wüstenrot Stiftung und Deutsche Verlags-Anstalt, 2006, 48-54. 


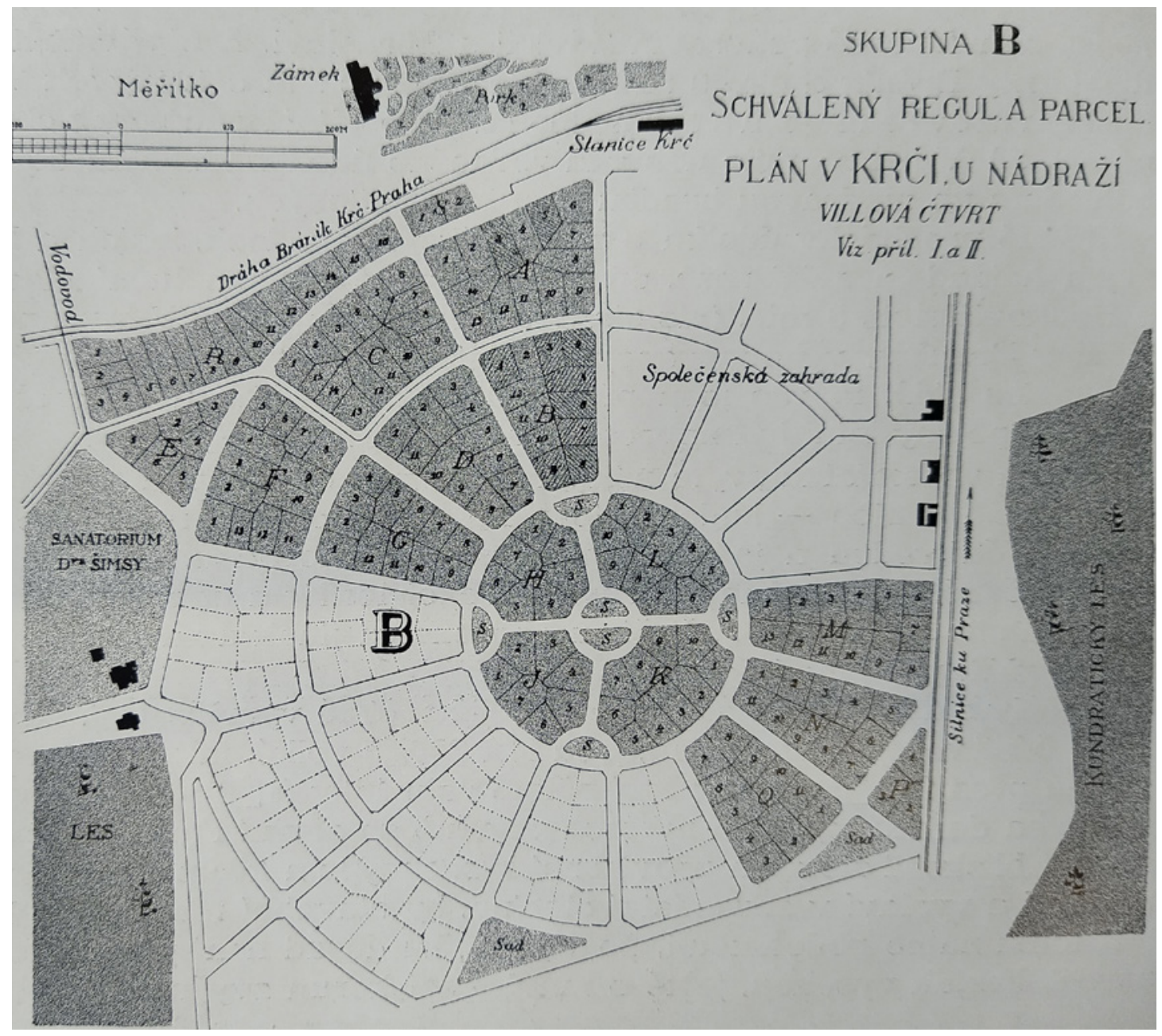

Figure 4: František Matějovský, Layout of the Garden City in Bráník and Krč by Prague, before 1911.

From: Tomáš Welz, Zahradní město v Bráníku a v Krči: villová čtvrt' v Praze XIII, Prague [1911].

\section{A capitalist garden city}

The First World War was marked by a long-term void in architectural production, and not only in Central Europe. The garden city in Krč was abandoned, unfinished, for housing budgets ceased to exist, architects left their professional backgrounds and were forced to put Austrian-Hungarian uniforms on. Nevertheless, one exceptional figure profited from the troubled situation to come. In the course of the War, the idea of garden cities was explored by Jan Koterra. With his expertise and the professional network that he had acquired, he was well prepared to initiate the first remarkable attempt to transfer the urban utopia into more precise terms in the Czech lands.

In comparison with other European regions, Kotěra's endeavour was conceived comparatively late, in a remote region, far from any big industrial centres, and under highly singular conditions. However, in the first decade of the twentieth century, Kotěra's œuvre ranged from pro- 


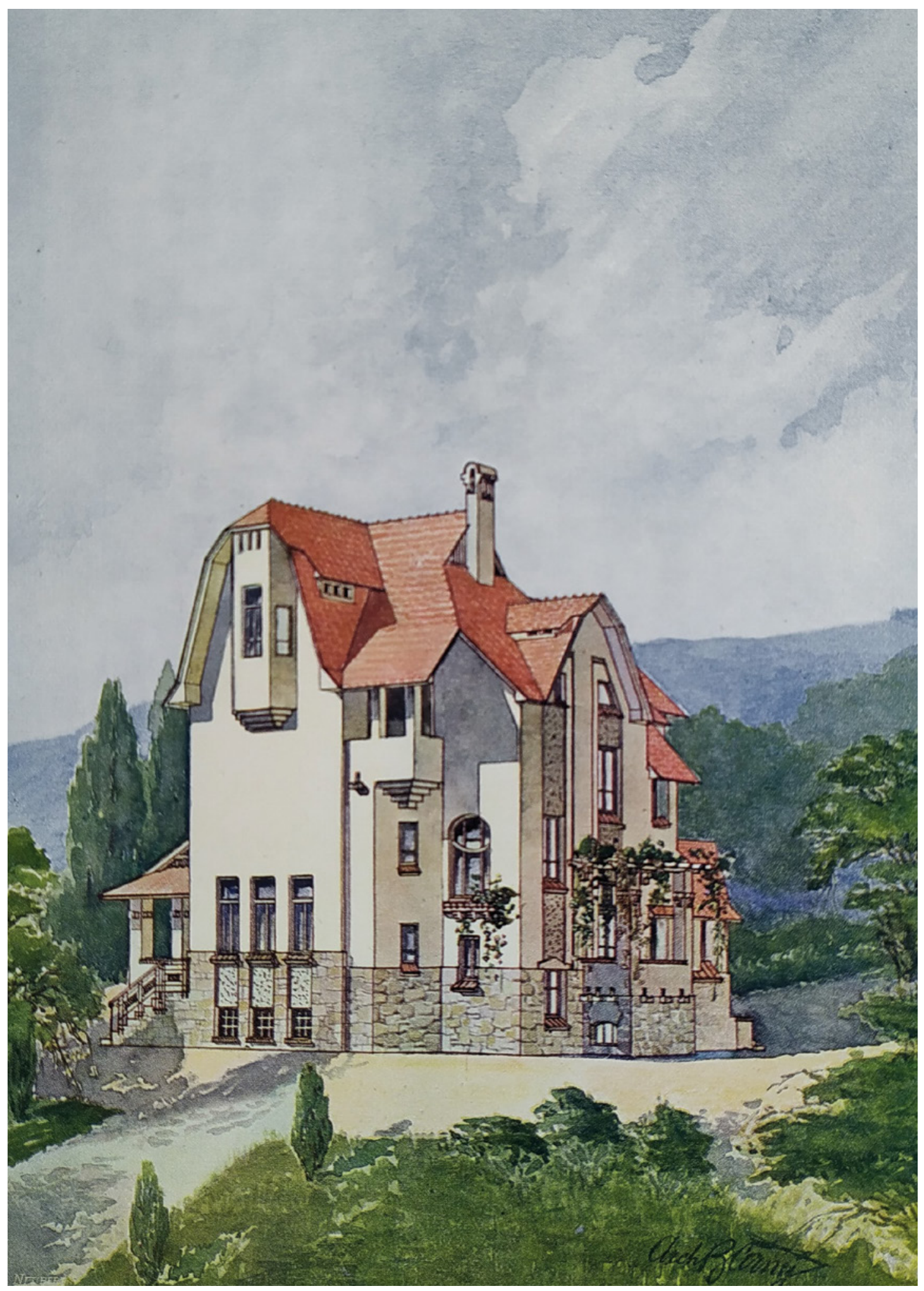

Figure 5: Bohuslav Černý, Model Family House for the Garden City in Bráník and Krč by Prague, before 1911. From: Tomáš Welz, Zahradní město v Bráníku a v Krči: villová čtvrt' v Praze XIII, Prague [1911]. 


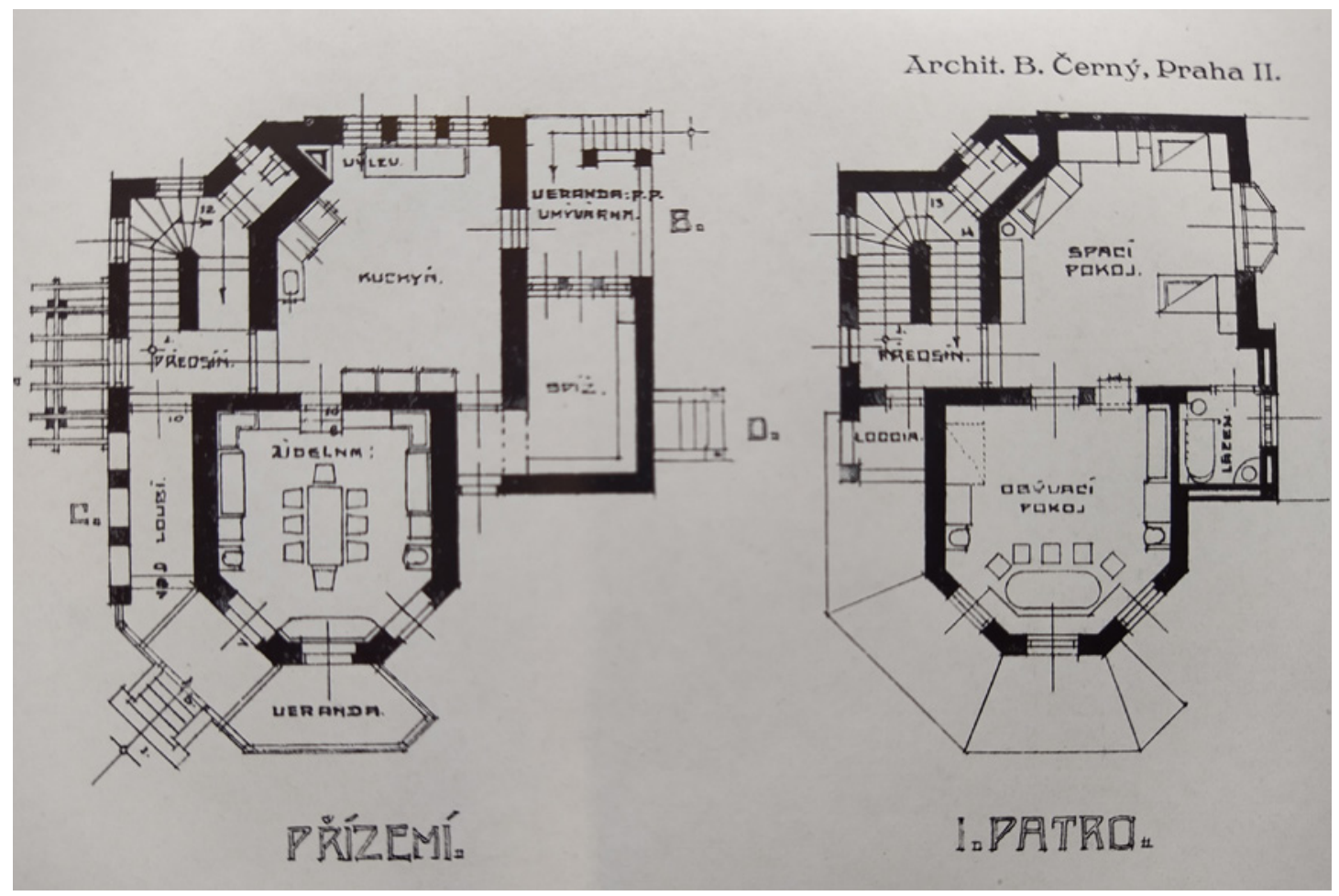

Figure 6: Bohuslav Černý, Model Family House for the Garden City in Bráník and Krč by Prague, before 1911. From: Tomáš Welz, Zahradní město v Bráníku a v Krči: villová čtvrt' v Praze XIII, Prague [1911].

jects of public buildings such as the Law and Theological Faculty in Prague to several workers' colonies in Louny or Králův Dvůr, as well as family residences on different scales and levels of luxury. Both of the housing typologies provided him with a rich experience needed for the urban assignment he was confronted with: he was appointed by a very affluent customer, Tomáš Bata, the leading shoe magnate based in the small town of Zlín, to design a vast extension to the town.

When war broke out, Bata succeeded in securing for his company enormous commissions for the supply of military shoes to the Austro-Hungarian army; the rapid increase in production was not matched by a comparable urban growth necessary for the workers and employees residing in Zlín. The cramped living conditions and lack of public amenities forced Bata to look for an appropriate solution. In 1915, Kotěra was appointed, with the task of developing Zlín to support the rapidly expanding business. In the times framed by the war economy and military recruitment, the intention was to set up a garden city in the vicinity of the Bata factory. Yet, implementing a garden city scheme into a town expansion commissioned by a single company owner sounds less like an experiment and more like a total contradiction. For whereas a garden city was to be a self-contained and self-governed community, the new settlement in the vicinity of the Bata factory was, in contrast, to be acquired, financed, and ruled solely by the company and its owner. Yet, it appears that during the war, such a utopian urban fusion was considered a joint vision shared by both Kotěra and Bata.

Kotěra's advocacy of the latest English model housing seemed to blend easily with Bata's personal concern with social issues and his special fondness for Leo Tolstoy's philosophy 


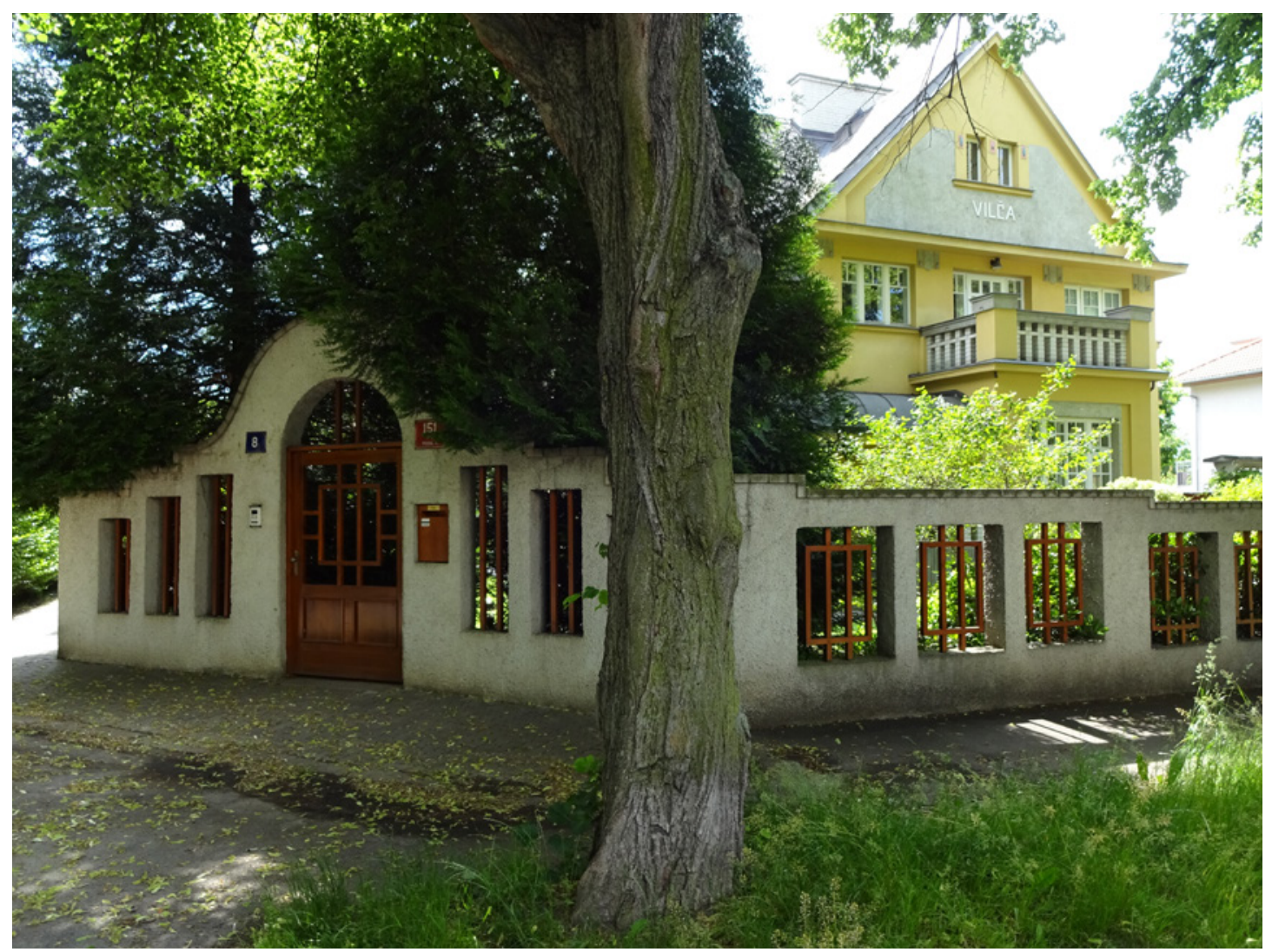

Figure 7: Rudolf Tuhý, The Villa 'Vilča' in the garden city in Bráník and Krč by Prague, 1911-1912. Photo: author.

commending the simple and allegedly unspoiled lifestyle in the countryside and a utopian factory in Émil Zola's novel Labour. ${ }^{47}$ In the middle of the 1910s, in a time affected by harsh war conditions, Tomáš Bata's left-leaning bias might have led him to support the garden cities movement without apparent difficulty. Despite being a successful self-made man in shoe production, director of an industrial concern operating on a global scale, Bata, looking backwards had labelled himself as 'a collectivist', 'a socialist', or, explicitly, as 'a Communist' in the years preceding the War. ${ }^{48}$

In 1940, when contemplating Bata's legacy, the keen promoter of garden cities, Alois Kubíček, did not hesitate to praise the overt capitalist Bata as the very personification of the ideal town founder depicted by Ebenezer Howard. ${ }^{49}$ Kubíček emphasized that 'it was an anxious foresight of a good landlord and a social thinker, knowing the maximum of settlement ideals. ${ }^{50}$ Yet, such an ideological background strictly contrasts with Bata's later economic models employed in his business plans, which focused on achieving maximum efficiency in the production and distribution of his goods. Following Henry Ford's innovations, Bata

47) Tomáš Bata, Úvahy a projevy [Thoughts and pronouncements], Prague: Dobrovský, 2013, 26.

48) Ibid., 26-28.

49) Alois Kubíček, 'Nové zahradní čtvrti ve Zlíně’ [The new garden quarter in Zlín], Architektura, 1940, special issue, 277.

50) Ibid. 
applied specialization of work processes, rationalization of production, standardization of design, and scientific management since the $1920 \mathrm{~s} .{ }^{51}$ Despite his extreme paternalism, employed in a dual role as the head of the concern and mayor of Zlín, he seems likely to have ideologically merged easily with Kotěra's expertise on the social reform stimulated by English garden cities when he commissioned one in Zlín next to his factory premises in the unstable period of the war.

Jan Kotěra started from scratch, with no intrusive townscape to consider in his urban design. He laid out a new settlement on the moderately sloping hills in the direct vicinity of the Bata shoe factory. ${ }^{52}$ The new urban pattern was arranged into low-density housing and several public buildings at a comfortable proximity to both work and nature. The master plan introduced a crescent form as a starting point of the over-all layout, a feature unusual for modern town planning, which was largely under the influence of Otto Wagner and was anchored in a rational pattern of precise grids. It is possible that Koterra adopted the crescent from the fashionable spatial relations in English towns, especially from the Georgian age, as it has no parallel in the local area. Still, it was not only an aesthetically satisfying solution but also a very functional arrangement aiming at creating an effective central point for reshaping the rather longitudinal valley (Figure 8).

In the centre of one of the crescents was 'a beehive,' a terrace of family houses directly adjoining the factory premises. ${ }^{53}$ From here streets gradually ascended, connecting the factory with the green belt surrounding the new development. The houses with pleasant views of the gardens and orchards avoided excessive density. Public buildings such as schools or office buildings were situated in the vicinity of the old town forming a certain transition between the two worlds. Focusing on the principles of the self-contained and economically self-sufficient community outlined by Howard was a key element employed in the development in Zlín. Two co-operative farms were also located in actual focal points of the estate that differentiated the new settlement from any other garden suburb. Having been planned in the course of the war, the aim of incorporating an agricultural base made sense in times when troublesome food supply shortages were a daily routine in the whole Habsburg monarchy, and the farms' own production may have provided a viable alternative to the local market. Furthermore, it also marked an important transition point for workers of usually rural origin while becoming accustomed to the radically different lifestyle of a rapidly growing industrial town. From a social point of view, therefore, the farms may have contributed to helping the former villagers adapt more easily to the brand new conditions in the new community.

During the course of the war, only the core of the new settlement was built. The eventual output, having been reduced to the beehive and several family houses, emphasises Bata's concern with the pressing housing issue in Zlín. All public amenities and the co-operative farms were omitted. The design of the simple buildings departed from English models, for

51) Ondřej Ševeček, Zrozeni Bat'ovy průmyslové metropole: Továrna, městský prostor a společnost ve Zlině v letech 19001938 [The birth of the Bata industrial metropolis: the factory, urban space and society in Zlín in the years 1900 to 1938], České Budějovice and Ostrava: VEDUTA and Ostravská univerzita, 2009, 55-59.

52) Jane Pavitt, 'The Bata Project: a Social and Industrial Experiment,' Twentieth Century Architecture, 1, Summer 1994, 37.

53) The ‘beehive' was hit by an air raid during WWII and the building was destroyed. 


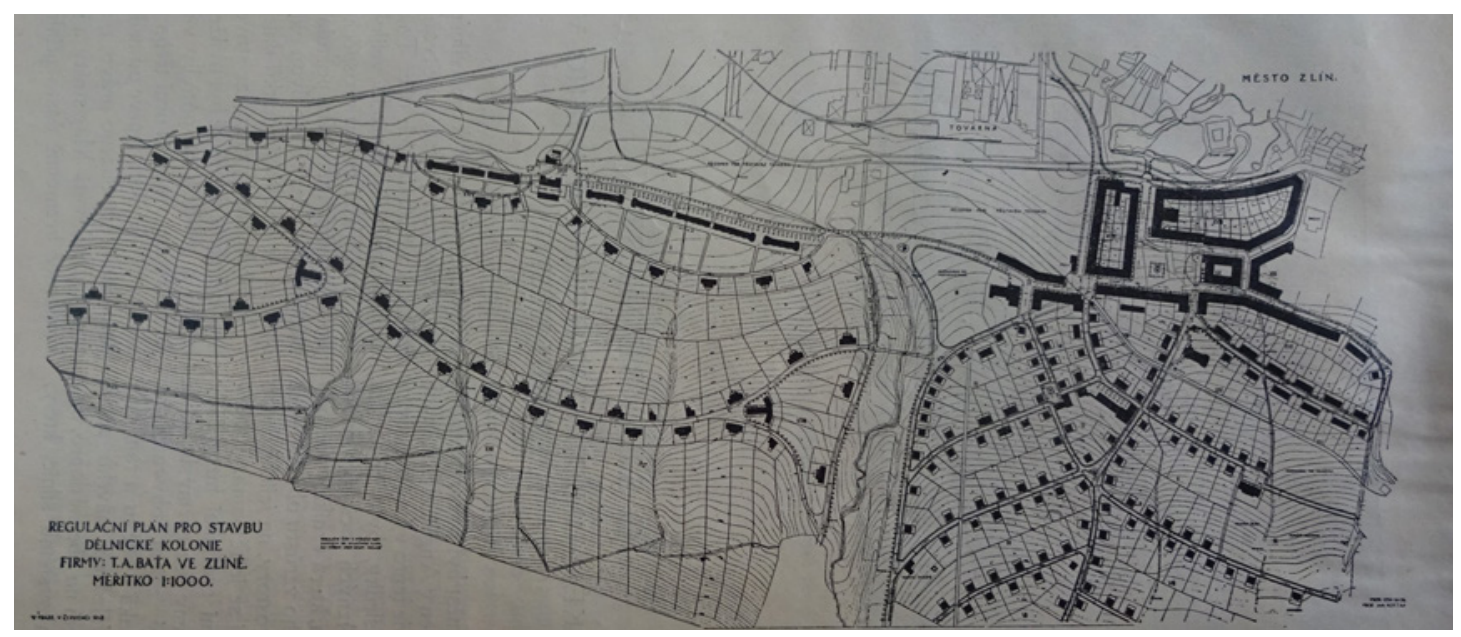

Figure 8: Jan Kotěra, Master Plan for Worker's Colony, Zlín, July 1918.

From, Jan Kotěra, Dělnické kolonie, Prague, 1921.

Kotěra employed a mansard roof as a key distinctive feature in his architecture. With their concern to address the housing shortage quickly, both Bata and Koterra ended up emulating the established tradition of workers' colonies in Germany, such as that in Margarethenhöhe near Essen that had been commissioned for employees of Krupp-Werke just a few years earlier, or Siemensstadt in Berlin (Figure 9).

Koterra's adoption of the garden city for the purpose of developing a workers' colony highlights the misapprehension of the social objectives incorporated in Howard's scheme. And in this sense, the colony was closer in concept to the slightly earlier development in Krč, where the building process also remained limited to mere housing, omitting any additional public amenities that may have provided a complex environment on the new urban and community model. No radical social reform took place in either the modern middle-class housing by Prague nor in that for workers in Zlín. Even though the newly built premises in both towns must have been praised highly by the families that moved in, these families definitely could not contribute to any significant social change (Figure 10).

\section{Translating the garden city to Czechoslovak reality}

The flirtation with the garden city idea in the Czech lands both before and during the war suggests that as the English scheme was adopted, its meaning and purpose changed. For it was adapted according to the private interests of particular developers. This observation was a common opinion among professionals, and was pointed out explicitly by a commentator in Styl: 'This name [garden city] was misused by several private enterprises. ${ }^{54}$ In order to counter this appropriation of the meaning of the reform vision for particular commercial purposes, František Fabinger, one of the keenest Czech pioneers of the movement, published a book

54) K. [Alois Kubíček?], 'Zahradní město v Praze' [The garden city in Prague], Styl, 1, 1920-1921, unpaginated: 'Pro různé podniky soukromé bylo bohužel tohoto názvu zneužito.' 


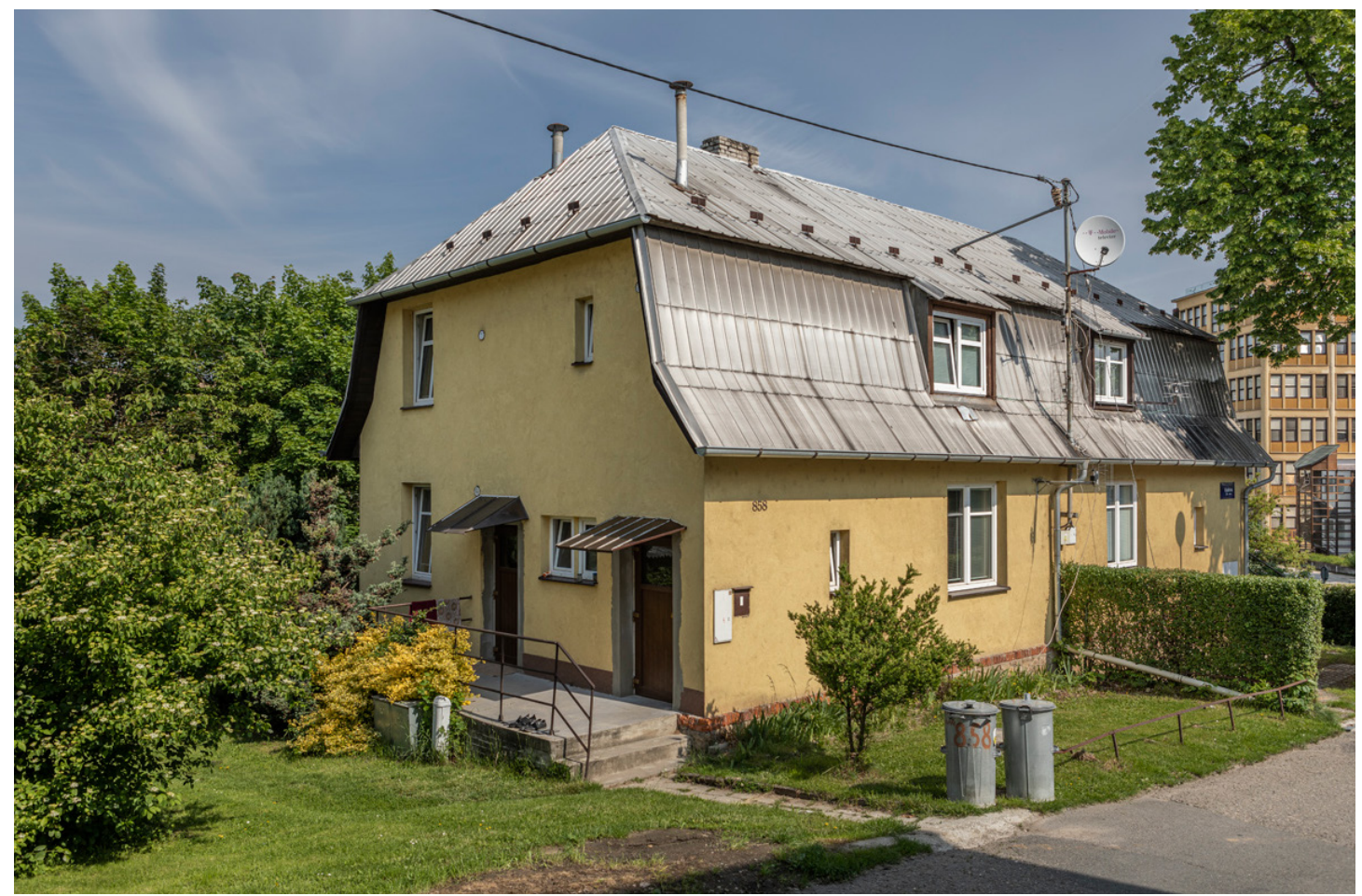

Figure 9: Jan Kotěra, House with four living units for Bata's workers' colony, Zlín, 1922-1923.

Photo: Petr Willert (onomonophotography).

with the long title The Housing Question and Soil Socialization. I. The Town of Tomorrow. The English Garden City according to E. Howard in $1920 .^{55}$

Fabinger, a grammar school teacher by profession and a determined promoter of Howard's vision, carefully identified which reform intentions were linked with the garden city idea. To provide the introductory insight necessary for potential dwellers of the garden city, Fabinger summed up his understanding of what a proper garden city should exactly be: ${ }^{56}$

A 'Garden City' is a settlement built on cheap land based on an advance plan that is well thought through and elaborate. The land remains the property of the company permanently settled there, and no part of the property may be sold to any individual. Building plots and agricultural land and, if needed, premises built on the estate are leased for any period to hereditary tenure. These measures prevent absolutely all land speculation and an increase in the value of the land solely as a consequence of the settlement will forever be secured for those who have merit in its increase, meaning the inhabitants of the garden city. This social and economic base ensures that every

55) František Fabinger, Bytová otázka a socializace půdy. I. Město zítřka. Zahradní město anglické dle E. Howarda [The housing question and the socialisation of the land I: the city of tomorrow. The English garden city according to E. Howard], Prague: self-published, 1920.

56) František Fabinger, 'Zahradní město' [The garden city], in Stavební družstvo Zahradní město. I. Stanovy, II. Jednací rád [The garden city building society I: Bylaws; II: Rules of procedure], Prague: self-published, 1920, unpaginated. 
inhabitant, even those who are less affluent, can have a garden and it is in this sense that we derive the name: GARDEN CITY. ${ }^{57}$

Fabinger's slightly simplistic version of the English garden city ethos for an audience untrained in modern town planning suggests that knowledge of urban design was not common; hence, the idea of the garden city was often reduced to that of a garden suburb by the general public. To what extent the garden city vision was (mis) understood among its sympathisers and professionals as well can best be illustrated by an example from the quarter of Ořechovka in Prague, one of the earliest and most prominent garden suburbs that were completed in the early years of Czechoslovakia. ${ }^{58}$

Ořechovka marks another shift in the meaning of 'garden city;' this time it was closely associated with the national movement, although not as explicitly as in the case of Masaryk City. If previous attempts to adopt the allusive name, garden city, referred to an idyllic way of dwelling amid gardens and also reflected private interests, now, with the establishment of Czechoslovakia, national political issues entered the scene. The civil servants in the new state were predominantly Czech speakers, as were the architects of all the successful entries submitted for the housing project in Ořechovka. The singular position of Ořechovka in modern Czechoslovak architecture and urban planning derives not only from the building programme but primarily from the Ministry of Public Works's ambition that it should act as a role model for future developments of its kind..$^{59}$ Not only were officials involved in the building of the colony proud of their achievement, in addition the German-language newspaper, Prager Presse, which was closely linked to the Czechoslovak establishment, praised the outcome: 'Here the state has really created an exemplary settlement, a garden city that, whether you like it or not, can be called exemplary in every respect; [...] The colony on "Vořechovka" which, with its community centre, cinema and school, is more of an independent city [...].'60

Only a couple of months after Czechoslovakia was founded, Ořechovka was just part of a vast construction programme in Prague that was launched jointly by the Ministry of Public Works and the Ministry of Social Care in the summer of 1919 to provide decent dwellings

57) 'Zahradní město' je osada, stavěná dle plánu předem dobře promyšleného a vypracovaného, na levném území. Toto území zůstává trvale majetkem společnosti na něm osídlené, a žádná část jeho neprodává se ve vlastnictví jednotlivci. Stavební místa a rolnické pozemky a eventuelně i budovy na pozemcích postavené pronajímají se na libovolnou řadu let do dědičného pachtu. Tímto opatřením zamezí se naprosto všechna spekulace půdou a přírůstek na ceně půdy, který byl způsoben právě jen jejím osídlením, jest na vždy zajištěn těm, kteří mají zásluhu o jeho vzrůst, to jest obyvatelům zahradního města. A tato sociální a hospodářská základna nové osady právě umožňuje, aby každý obyvatel, i méně majetný, měl svou zahradu, a odtud název: ZAHRADNÍ MĚSTO.' Fabinger, 'Zahradní mesto,' unpaginated.

58) Josef Havlíček, Kolonie "Vořechovka", Prague: Ministry of Public Works, 1924; Alexandra Kř́žová and Kateřina Hubrtová, 'Moderní architektura Střešovic. Od celku k detailu 1: Ořechovka' [The modern architecture of Střešovic. From the whole to the detail 1: Ořechovka], Staletá Praha, 26: 2, 2010, 109-121.

59) Vendula Hnídková, ‘Ořechovka. Reformní ideje za kulisou buržoazního blahobytu’ [Ořechovka: the reform ideas behind the mise-en-scène of bourgeois prosperity] in Veronika Rollová and Cyril Ř́ha, eds., Art and Evolution: Festschrift pro Jindřicha Vybirala, Prague: UMPRUM 2020, 346-360.

60) J. H. [?], 'Eine werdende Stadt. Die Vořechovka. - Prags Wohnstädte in der Zukunft: Bubeneč und Dejvice. Das Belvedere und seine Verbauung,' Prager Presse, 4: 226, August 1924, 4: 'Hier hat der Staat wirklich einmal eine vorbildliche Siedlung geschaffen, eine Gartenstadt, die man, ob man will oder nicht, in jeder Beziehung mustergültig nennen kann; ... Die Kolonie auf der „Vořechovka“, die mit ihrem Gemeindehaus, ihrem Kino und ihrer Schule eher eine selbständige Stadt ist.' - Vořechovka is not a German translation of Ořechovka but an old name of the location. 


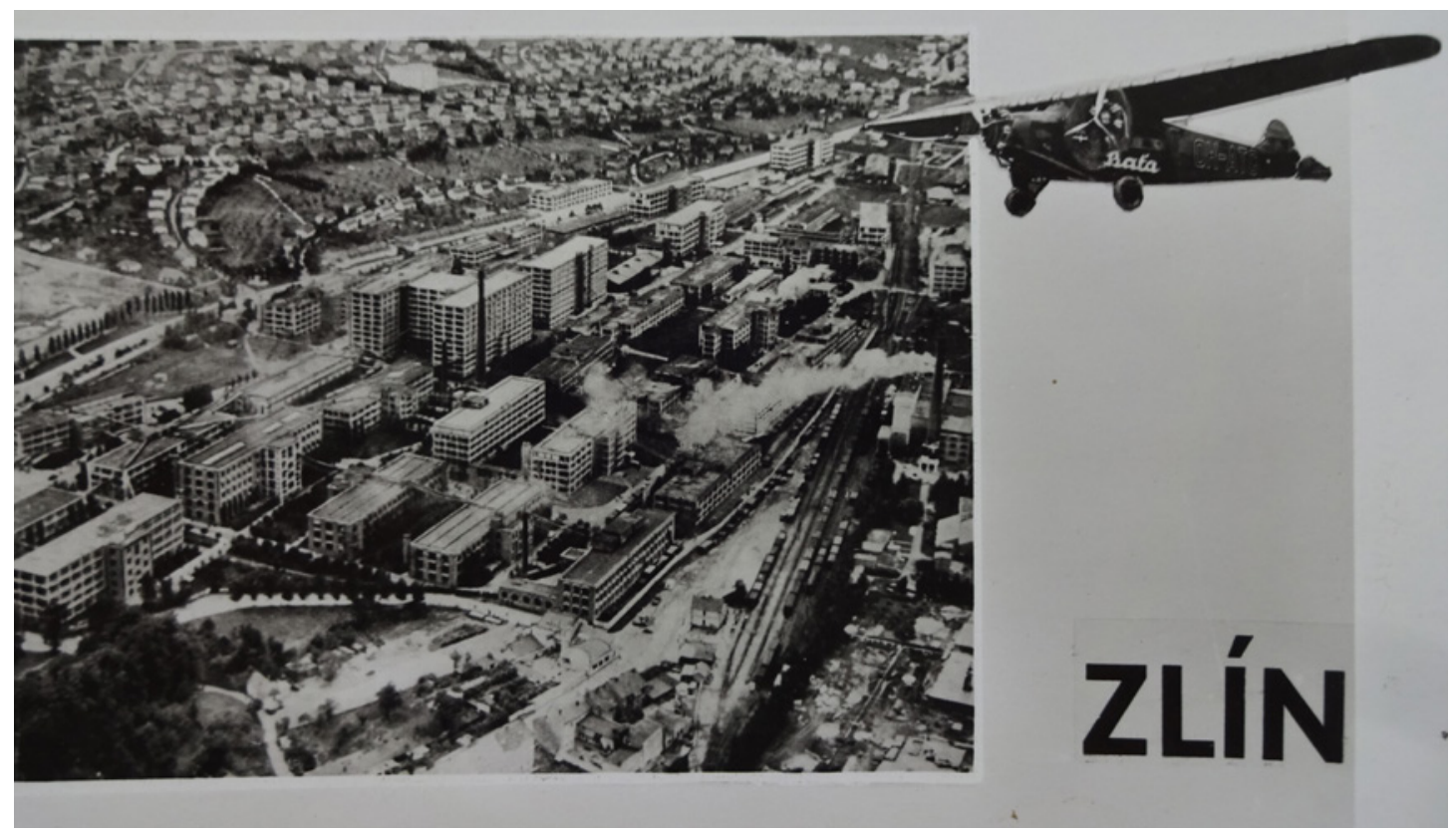

Figure 10: Zlín, Aerial View. In the upper part of the image is the Kotěra's town extension with two small crescents along the main road.

Source: Historic Postcard. Author's collection.

for civil servants in a harsh housing crisis in the aftermath of the war. ${ }^{61}$ As was common practice, an architectural competition was prepared and architects submitted almost forty proposals. ${ }^{62}$ Josef Havlíček, a high official of the Ministry of Public Works who was in charge of Ořechovka development, summarised the final achievement with apparent satisfaction. He emphasized that it was a colony shaped by modern directions in the construction of 'garden cities.' ${ }^{63}$ But his own words reveal the use of contradictory meanings for 'garden city' which was, for him, synonymous with 'a housing colony', lacking any programme for a social transformation (Figure 11).

Today, the urban plan of the 1920s has been swallowed up by later developments in the area. The master plan by the Czech architects Jaroslav Vondrák (1881-1937) and Jan Šenkýr (18851948) was outlined on the basis of a rather formal street layout that formed a small centre with a main public building as its focal point. The volume of the latter is symmetrically divided into two wings with a passage in its very heart resembling a town gate. Again, the volume of the building resembles the workers' colony Margarethenhöhe in Essen or Liebigstadt in Liberec. The centrally located, multipurpose building was a bulky structure incorporating several services ranging from a grocery store, a cinema, and a restaurant. Also, the presence of a pub marks the rather socially inclusive character of the newly developed neighbourhood. In Ořechovka examples of terraced houses in the cottage style were also introduced, recalling their English predecessors in a straightforward way.

61) Hynek Kubišta, 'Politika stavební a bytová' [Planning and housing politics], in Československá vlastivěda, 6, Prague: Sfinx, 1930, 319-338.

62) Hnídková, 'Ořechovka,' 346-357.

63) Havlíček, Kolonie "Vořechovka”, 16. 


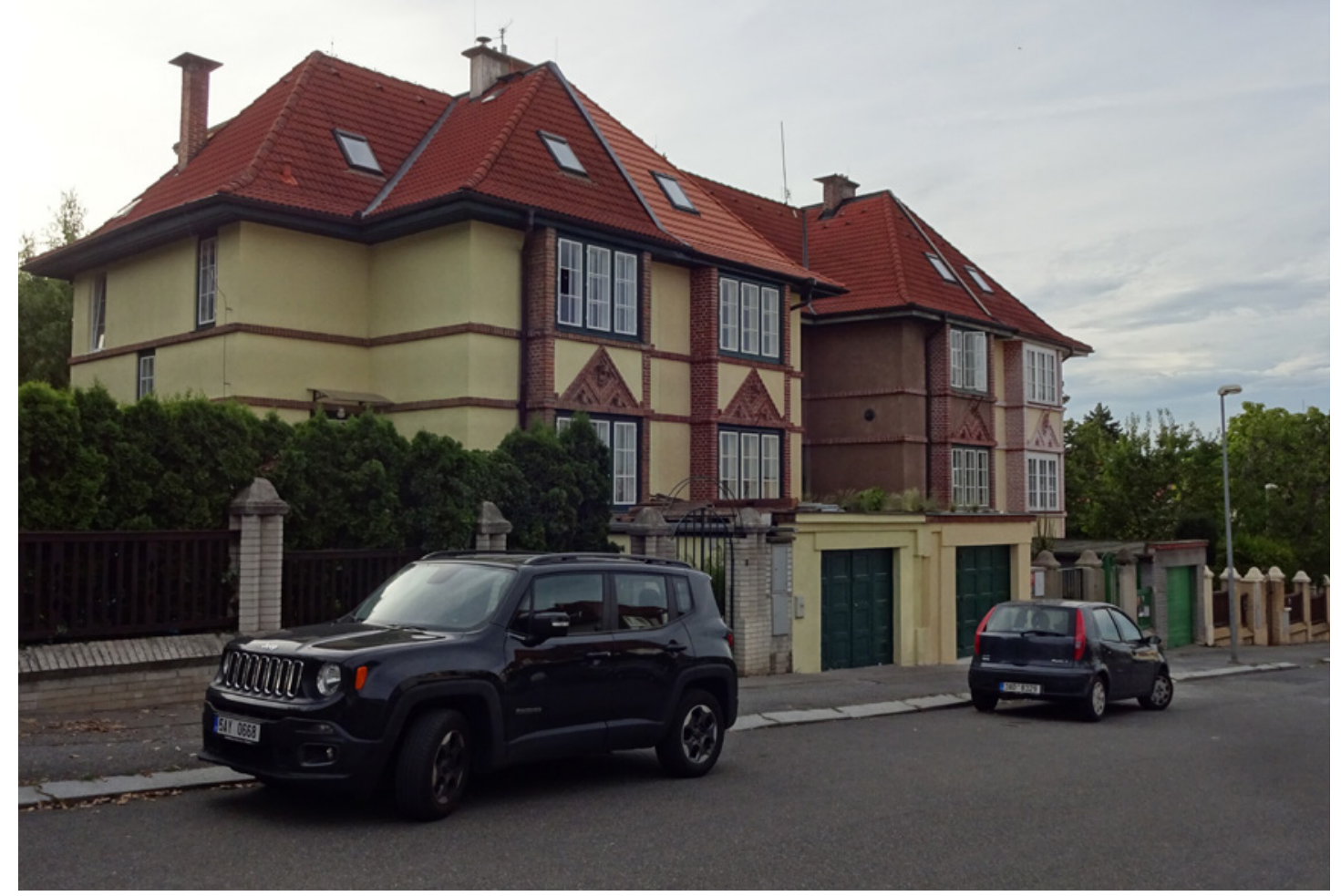

Figure 11: Jaroslav Vondrák, Terraced Houses in Garden Suburb Prague - Ořechovka, 1920-1921. Photo: author.

The prominence of Ořechovka, confirmed by its exemplary role for further developments in Czechoslovakia, may be attributed to the prevailing confusion between the garden suburb and the garden city, which has contributed to the recurrent misuse of the latter term. Later on, the widely accepted model of Ořechovka was followed and expanded on in other garden suburbs such as Spořilov or Zahradní město (literally meaning 'Garden City') in Prague. ${ }^{64}$ In fact, these garden suburbs prove that it was not only Ebenezer Howard and his various local sympathisers who longed for settlements where the differences between town and country would dissolve to create a harmonious, healthy, and happy community. Nevertheless, the Czech advocates of garden cities usually did not long for anything more than a carefully designed built environment with family houses, avoiding any uncomfortable merging of social classes (Figure 12).

Although criticised, the Ořechovka garden suburb was intended to serve as an example of model housing and as such was not emulated in other projects within Czechoslovakia; the estate was added to the carefully curated collection of monuments and cultural heritage sites, such as Prague Castle, that were showcased to prominent foreign visitors. As early as 1924, Henry Chapman, the representative of the International Garden Cities and Town-Planning Federation, had enjoyed a guided tour of the sloping streets of Ořechovka. His eye was caught

64) Karel Polívka and Vlastimil Brožek, 'Spořilov', Architekt SIA, 27, 1928, 179-187. 


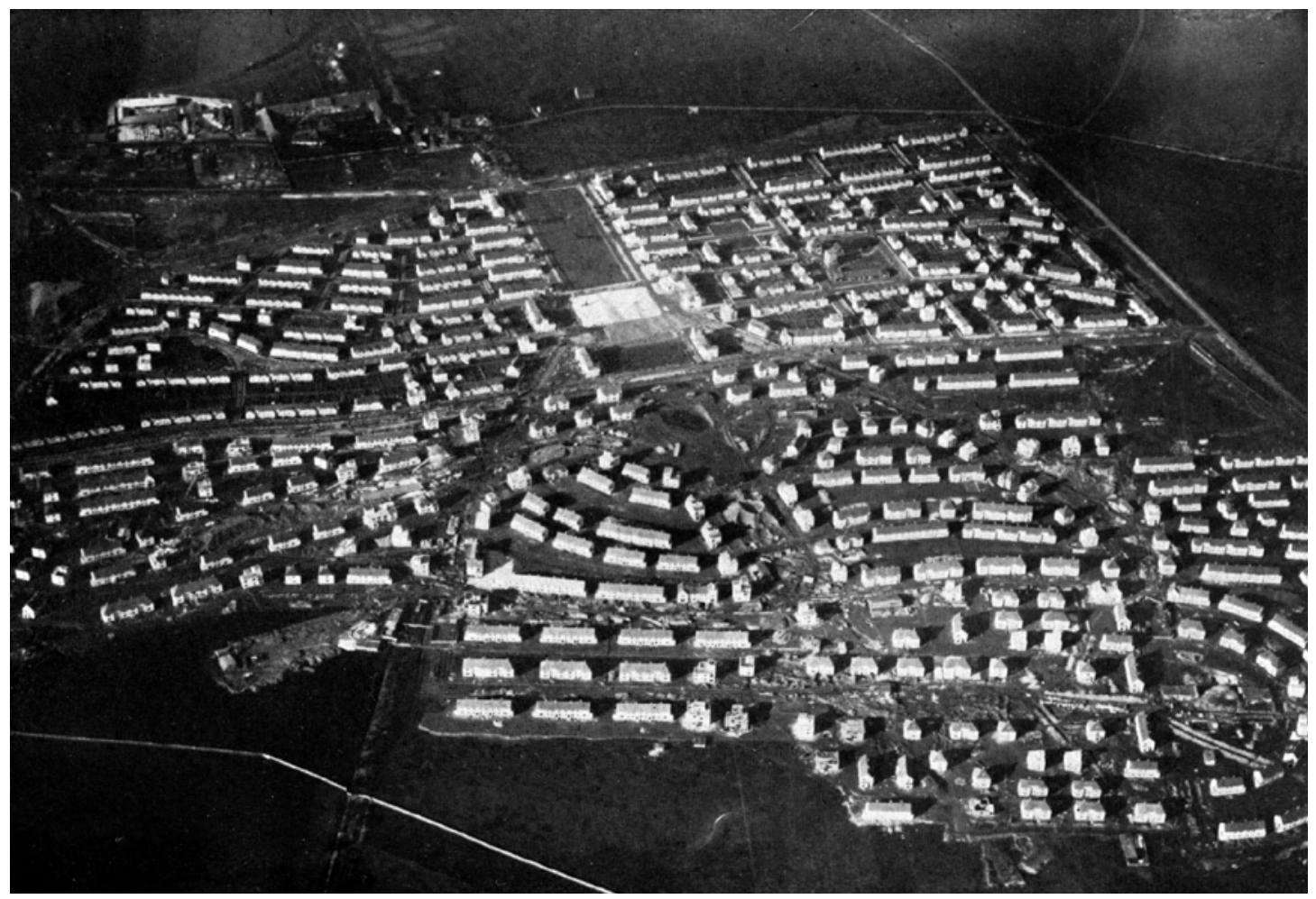

Figure 12: Vlastimil Brožek and Karel Polívka, Garden City Prague - Spořilov, 1925-1928.

Source: Architekt SIA, 27, 1928.

not only by the modern architecture but, from his English point of view, by the stratified social division of the occupants. Upon arrival to the UK, he approvingly reported with deep affection in the British media that 'The President of the Parliament lives in one of the houses, surrounded by civil servants of all grades. .... ${ }^{65}$ Yet, the positive impression skipped over any issues concerning the fact that the actual nationality of the residents was predominantly Czech. Ořechovka was commissioned by the Czechoslovak government for its employees who were principally Czech, as well as the architects of the new district.

Only one year before Henry Chapman's visit, in 1923, another prominent visitor from Britain arrived in Prague: renowned architect, town planner, and architect of the first garden city Letchworth, Raymond Unwin. On the occasion of this, the town planning department of Prague, the State Regulatory Commission, arranged a special presentation of the local urban plans. ${ }^{66}$ In his welcome speech, the president of the Commission, Eustach Mölzer felt the need to emphasize the fact that 'The plan to ensure Greater Prague's successful future development was hampered by the consequences of the 300-year subjugation of the Czechoslovak people, which did not allow for the construction of the towns to develop

65) Henry Chapman, 'Old Prague and Developments in Czecho-Slovakia', Garden Cities ETown Planning. A Journal of Housing Town Planning \& Civic Improvement, 14:7, 1924, 150-153.

66) Státní regulační komise pro hlavni město Prahu s okolím [State regulatory commission for the capital city of Prague and its environs]. 
politically, socially and hygienically. ${ }^{97}$ No doubt, Unwin must have been confused by this Czech animosity towards Germans for, given the extensive cultural transfer involved, the garden city movement broke the established hostility between the Czechs and Germanspeakers living in the Czech lands.

Unwin was welcomed with the highest honours by all sections of the garden city movement in Prague. Like many other artists and intellectuals, he was invited by President Masaryk to his official residence at Lány castle for lunch. ${ }^{68}$ The Czech Society of Architects conferred honorary membership of their Society on him, and he also gave a lecture on garden cities and town planning to a large audience at the Philosophical Faculty of Charles University. ${ }^{69}$ To the great astonishment of the Czech architects, Unwin's personality and expertise was able to bridge the tensions between local architects of both nationalities based in Prague, Czech and German, at least for that one evening. ${ }^{70}$ At a farewell dinner given by the Czech Society of Architects, they were able to discuss the urban issues of the day without any inter-ethnic tension. Nevertheless, the Czech architectural media and daily press omitted any mention of the fact that The German University in Prague had conferred an honorary degree of Doctor of Technology upon Unwin or that the German League of Nations in the Czechoslovak Republic (Deutscher Völkerbundliga in der Tschechoslowakischen Republik) had held a welcome evening for him at the German House. ${ }^{71}$ It certainly was no accident that the pacifist Unwin presented his ideas on nationality to the German audience.

Yet, the positive impact of Unwin's visit emphasises the fact that in housing issues and in the garden cities in particular, Czech architects did not hesitate to recognize certain outcomes that were achieved in this field in Germany. In this sense, the rather positive evaluation of housing reform in Germany provides a straightforward model that was studied, acknowledged, and emulated in the pre-war period in the Czech lands. However, with the radical shift in political power after Czechoslovakia was founded, the local Germans residing in Czechoslovakia were excluded not only from the government for a long time but also from any participation in architectural production representing the state, as a gesture of historical satisfaction applied by the local authorities, who were predominantly Czech. ${ }^{72}$

67) 'Raymond Unwin in der Staatlichen Regulierungskommission', Prager Presse, 3: 145, May 1923, 2: 'Der Plan, der Groß-Prag eine ersprießliche Entwicklung in der Zukunft sichern soll, sei durch die Folgen der 300jährigen Unterjochung des tschechoslowakischen Volkes erschwert, die es nicht zustießen, dass sich der Bau der Städte in politischer, sozialer und hygienischer Hinsicht so entwickeln konnte.'

68) 'Mr. Raymond Unwin's Visit to Prague', Garden Cities \& Town Planning, 13: 6, 1923, 118-119.

69) Raymond Unwin, 'Stavba měst' [Town planning], Styl, 9, 1923-1924, 79-91.

70) 'Architekt Raymond Unwin do Prahy', Národní listy, 63: 119, 1923, 1; Zs, 'Přednáška architekta Raymonda Unwina', Národní listy, 63: 145, 1923, 4; 'Architekt Raymond Unwin,' Lidové noviny, 31: 268, 1923, 5; 'Anglický architekt Raymond Unwin,' Lidové noviny, 31: 266, 1923, 5; 'Architekt Raymond Unwin,' Národní politika, 41: 130, 1923, 10; 'Raymond Unwin v Praze', Styl, 9, 1923-1924, 22; 'Návštěva arch. R. Unwina v Praze', Styl, 9, 1923-1924, 73-74.

71) 'Mr. Unwin in Prag', Deutsche Zeitung Bohemia, 96: 116, 1923, 5; 'Mr. Unwin in Prag', Reichenberger Zeitung, 64: 116, 1923, 6.

72) Mary Heimann, Czechoslovakia. The State that Failed, London and New Haven: Yale University Press, 2009, 48-49. 


\section{The Institute for Town Planning at the Masaryk Academy of Labour}

The historical triumph of the founding of Czechoslovakia linked some Czech architects and reformers with the idea of building Masaryk City at White Mountain in 1920, yet this pioneering vision only got as far as launching a largescale campaign in favour of garden cities, without the project ever materializing. Two years later, in order to achieve a more pertinent platform for the dissemination of the concept of garden cities, some of the Czech garden city sympathisers led by the architects Vilém Dvořák (1886-1937), Vladimír Zákrejs (1880-1948), and Otakar Fierlinger (1888-1941) founded the Institute for Town Planning at the Masaryk Academy of Labour (Ústav pro stavbu měst při Masarykově akademii práce). ${ }^{73}$ The Academy bearing the name of the Czechoslovak president aimed at implementing technical expertise into industry, business, and everyday life. ${ }^{74}$ The singular attribute of the Academy was a consulting service provided by experts. In the case of the Institute for Town Planning, the architects dedicated their time and knowledge to correcting and envisioning new urban developments for particular towns.

A key objective of the expert department was to spread the latest expertise on town planning in Czechoslovakia. The newly emerging field had no independent base and one of the objectives listed in the official programme of the Institute, was to build garden cities. ${ }^{75}$ Significantly, the Institute was joined by several supporters of the scheme who had promoted the establishment of garden cities in the vicinity of Prague already before the war, and who continued to advocate the same vision also in the 1920 s.

During the 1920s and 1930s, the Institute was joined by many high-profile architects, technical experts, and influential members of the public administration. In its initial stages, members of the Institute became active members of The International Federation of Housing and Town Planning. One of the most active professionals of the Institute was Otakar Fierlinger, a prolific author, garden architect, landscape specialist and urban planner. ${ }^{76}$ Having studied in Vienna, at Harvard University and Ann Arbor in Michigan he had a broadbased international education. Thanks to his language skills and broad expertise, Fierlinger represented the Institute at many international conferences. After Czechoslovakia was founded, he was appointed to the Ministry of Public Works where he became the head of the Department of Urban Planning in the 1930s. By then, the Great Depression had hit Czechoslovakia hard and the authorities were trying to cope with desperately high rates of unemployment.

73) Pavel Kodera, 'Ústav pro stavbu měst při Masarykově akademii práce' [Institute for Town Planning at the Masaryk Academy of Labour], in: Instituce, osobnosti, ideje a struktura vědy v českých zemích [Institutions, persons, ideas and the structure of science in the Czech lands], Prague: Archive of the Czech Academy of Sciences, 2007, 243-261.

74) Emilie Těšínská and Jindřich Schwippel, 'Masarykova akademie práce’ [The Masaryk academy of labour], in: Alena Míšková, Martin Franc, and Antonín Kostlán, eds., Bohemia docta. K historickým kořenům vědy v českých zemích [Bohemia docta. On the historical roots of science in the Czech lands], Prague: Academia 2010, 286-318.

75) 'Ústav pro stavbu měst při Masarykově Akademii práce v Praze' [The institute of town planning of the Masaryk academy of labour in Prague], in: Otakar Fierlinger, Nutnost péče o výstavbu obci venkovských [The need to care for the building of rural settlements] Prague: The Institute of Town Planning of the Masaryk Academy of Labour, 1923, unpaginated.

76) Otakar Fierlinger was also brother of Zdeněk Fierlinger, leader of the Social-Democrats who joined the party with the Communist Party. 
As a proper solution to the housing crisis, the Ministry of Public Works aimed at constructing districts for unemployed workers and their families outside of Prague. ${ }^{77}$ Every family was to receive a simple detached house with a small garden in newly established satellite towns. But neither aesthetics nor urban planning were the leading principles. The objective of the political representation was twofold: The scheme was meant not only to provide housing but also a significant means of supporting the diet of families in need. Daily work at the private allotments was to replace the jobs lost in the factories.

In the case of workers' colonies, the new dwellings might have provided a higher standard of living for the unprivileged classes in comparison to the existing city slums but at the price of total spatial and social segregation. Furthermore, affordable housing of this kind would be affected by the lack of infrastructure, services, schools and medical care, not to mention the transport connections to towns. Had the developments been eventually completed, the families living there would have been able to practice farming and agriculture, but it would have been highly unfeasible to commute to industrial centres, if jobs reappeared. As a consequence, the overtly paternalistic goal would have provided attractive accommodation, but at the price of total subordination to the limits of the newly conceived settlement.

In 1933, Otakar Fierlinger discussed the idea of the workers' colonies in public at a national conference of architects that took place in Brno. Fierlinger's bold proposal received a negative response immediately from the audience and provoked Karel Teige to articulate an opposing attitude in the pamphlet Garden Cities of the Unemployed. ${ }^{78}$ Teige, a respected author and representative of overtly leftist positions in the Czech art world, regarded the official intention as clearly dubious. First, he rejected its origins in English garden cities. In general, the leftist avant-garde distanced itself from the garden city movement due to the latter's exclusive focus on the middle class and its housing concerns, neglecting the unprivileged working class. This was in fact a false interpretation of Ebenezer Howard's objectives, but it was characteristic of how leftists interpreted his ideas.

Second, he compared these settlements to urban planning ideas in fascist Italy and Germany, specifically, the promotion of so-called Stadtrandsiedlungen; moving workers to such developments, Teige claimed, chained them to the soil. ${ }^{79}$ In fact, the National Socialist new garden suburbs stood in direct contradiction to the socialist roots of the garden cities movement. The key difference between their urban plans is embedded in the simple distinction of the particular models informing both schemes in their response to modern society. While the National Socialist settlements were to emulate a traditional village, the English reform vision intended to improve an existing urban model by fusing it with nature not by upgrading to a village. ${ }^{80}$

Though there were rehousing initiatives in Germany, Italy, and Austria, Teige's simplifying comparison missed the point. Rather than comparing Fierlinger's aim to Stadtrandsiedlungen in Germany, he would have found a more appropriate parallel in the settlement move-

77) 'Anketa o sídlištích na obvodu měst' [Questionnaire on the settlements on city outskirts], Stavba, 11, 1932-1933, 143-144.

78) Karel Teige, Zahradní města nezaměstnaných [The garden cities of the unemployed], Prague: Levá fronta, 1933.

79) Ibid., 6.

80) Gerhard Fehl, 'The Nazi Garden City', in: Stephen V. Ward, ed., The Garden City. Past, Present and Future, London: E \& F N Spon 1992, 88-106. 
ment called Gartensiedlungen in Austria, which was promoted by Gustav Scheu, a follower of Ebenezer Howard. Scheu, a committed proponent of the common ownership of land and communities based on co-operative principles, was appointed as a municipal advisor on housing matters in the social democrats' Red Vienna in $1919 .{ }^{81}$ Scheu, upon entering the office, designated his close friend and the architect of his family house in Hietzing, Adolf Loos, as the chief architect of the Housing Office (Siedlungsamt). Teige, blinded by the very limits of his leftist ideology, omitted the preceding example from his critical assessment although he must have been familiar with Loos's reform initiative as he acknowledged the architect's work in general.

No matter what the origin of the envisioned workers' colonies was, the experts gathered at the Institute for Town Planning and at the Ministry of Public Works conceived a plan that would significantly contribute to the social segregation of the communities. What the newly established settlements would facilitate, however, was the sort of improvement from above believed necessary by the Masaryk Academy of Labour to secure a technically based promotion of society to survive the crisis and to pledge for a better future. The plans were eventually never adopted in any colony and the ideas survived only in the expert discourse.

\section{Conclusion}

The climax of the garden cities movement in the Czech lands spans the first four decades of the twentieth century, yet the English scheme was transformed several times and shifted to an altered reading. Eventually, despite numerous private and public initiatives, the garden city idea was never implemented in the Czech lands in its totality. The actual meaning of the garden city was usually lost in very ambiguous appropriations of Howard's concept and subsequently translated into various local versions. Then, the history of the garden city movement performs a series of highly speculative approaches to the English utopian vision.

In addition to that, there is a parallel story to the garden city movement in the Czech lands. In the historical lands of the Bohemian crown there was a lasting national conflict between the Czechs and Germans and this permanent struggle is indeed reflected in the translation of the garden city scheme but with a shifting assessment. The German campaigning in favour of garden cities and the early examples of built settlements were praised by the Czech professionals before the war and suppressed in its aftermath. In brief, the political situation in Central Europe was reflected here in the attitude toward the garden city movement pioneered in Germany.

81) Eve Blau, The Architecture of Red Vienna, 1919-1934, Cambridge and London: The MIT Press, 1999, 91-110. 